\title{
THE CHALCOLITHIC OF SOUTHEAST ANATOLIA
}

\section{RANA ÖZBAL}

THE Chalcolithic period in southwest Asia covers over 3,000 years, from the beginning of the sixth to the end of the fourth millennium cal B.C.E. In comparison with the well-researched Neolithic and the Urban Revolutions between which it is sandwiched, the Chalcolithic has received considerably less attention. Because it is geographically part of the Fertile Crescent, the archaeological styles, cultural elements, and developments in southeast Anatolia were closely connected to those in northern Mesopotamia. Trade and economic relations continuing over the millennia and analogous social and political trajectories have contributed to a high degree of regional interdependence. Moreover, the lack of well-defined local southeast Anatolian ceramic sequences (excluding perhaps the Amuq region), has resulted in a threefold division of the cultural chronology based on the better defined northern Mesopotamian Halaf, Ubaid, and Uruk or Late Chalcolithic phases. The easily distinguishable painted wares of the Halaf and Ubaid periods and the distinctive shapes of the Uruk phase are such hallmarks that they tend to override local ceramic assemblages. Moreover, local ware groups seem to show variability within southeast Anatolia, and identifying dominant supraregional styles has proved difficult. One of our aims should be to construct local typochronological markers and to see how they vary from subregion to subregion.

Although the cultural similarity between these supraregional areas during the Chalcolithic is undeniable, one could argue, especially for the Halaf and Ubaid phases, that some of the stylistic overlap may be a result of Mesopotamia-centric research traditions and related biases in publications. Distinct local and regional differences between southeast Anatolia and the north Mesopotamian steppe cannot 
be ignored. This chapter attempts to provide a balanced overview of both local and Mesopotamian-influenced styles and traditions in the Chalcolithic of this region. Rather than supply the reader with a compendium of every excavated Chalcolithic site, I outline general characteristics and present a few key settlements. The discussion of the Chalcolithic is chronologically divided into millennia, based on calibrated dates. The sixth, fifth, and fourth millennia B.C.E., respectively, roughly refer to the Early, Middle, and Late Chalcolithic in which Halaf-, Ubaid-, and Uruk-type materials are correspondingly prevalent.

Overall, the Chalcolithic of Anatolia has come a long way from the "dark age" that it was labeled three decades ago (Burney 1977:118, 120). In particular, the Upper Euphrates Valley in southeast Anatolia has been intensively researched since the late 1970 as surveys and excavations have focused in regions affected by dam lakes, and as many Mesopotamian archaeologists have set up research projects in Turkey following the Gulf Wars.

\section{GEOGRAPHY}

Archaeologically speaking, the most important geographical features characterizing this region are the Euphrates and Tigris River valleys, since most known Chalcolithic sites are located along the rivers and their tributaries (figures 8.1, 8.2). These riverine environments have been the most intensively surveyed and investigated, especially, as mentioned, prior to the many dam-building projects.

Southeast Anatolia is bounded to the north by the 2,000-3,000 $\mathrm{m}$ high Taurus and Anti-Taurus mountain chains. Earlier assumptions that the mountain range marked the limit of north Mesopotamian influence (e.g., Dönmez and Brice 1949) have been challenged by the discovery of "Esh-Sheikh-type" Ubaid wares in the Elbistan Plain (Brown 1967) as well as Halaf, Ubaid, and Uruk-related pottery in the Keban Dam area of the Upper Euphrates region (Aksoy and Diamant 1973; Esin and Arsebük 1974; Gülçur 200o; Hauptmann 1976, 1982; van Loon 1978; Wright and Whallon 1998). North Mesopotamian-influenced occupation during the Chalcolithic also occurs on the highland plateaus and the undulating piedmont zones of Maraş, Adıyaman, Malatya, Muş, Diyarkabır, Batman, and Van, which form the Taurus foothills (Blaylock 1998; Blaylock, French, and Summers 1990; Carter et al. 1997; Carter, Campbell, and Snead 1999; Gürdil 2002; Korfmann 1982; Ozan forthcoming; Parker and Creekmore 2002; Reilly 1940; Rothman and Kozbe 1997; Yakar and Gürsan-Salzmann 1978). To the south of the foothills lie the lowland plains of the Amuq, İslahiye, Kilis, Birecik, Suruç, Harran, Mardin, Cizre, and Silopi, west to east, respectively.

The Euphrates and Tigris Rivers cut through these landforms, forming steep gorges in some places and broad alluvial plains in others, further shaping the geography. The two river valleys are geologically divided by the Karacadağ volcanic 


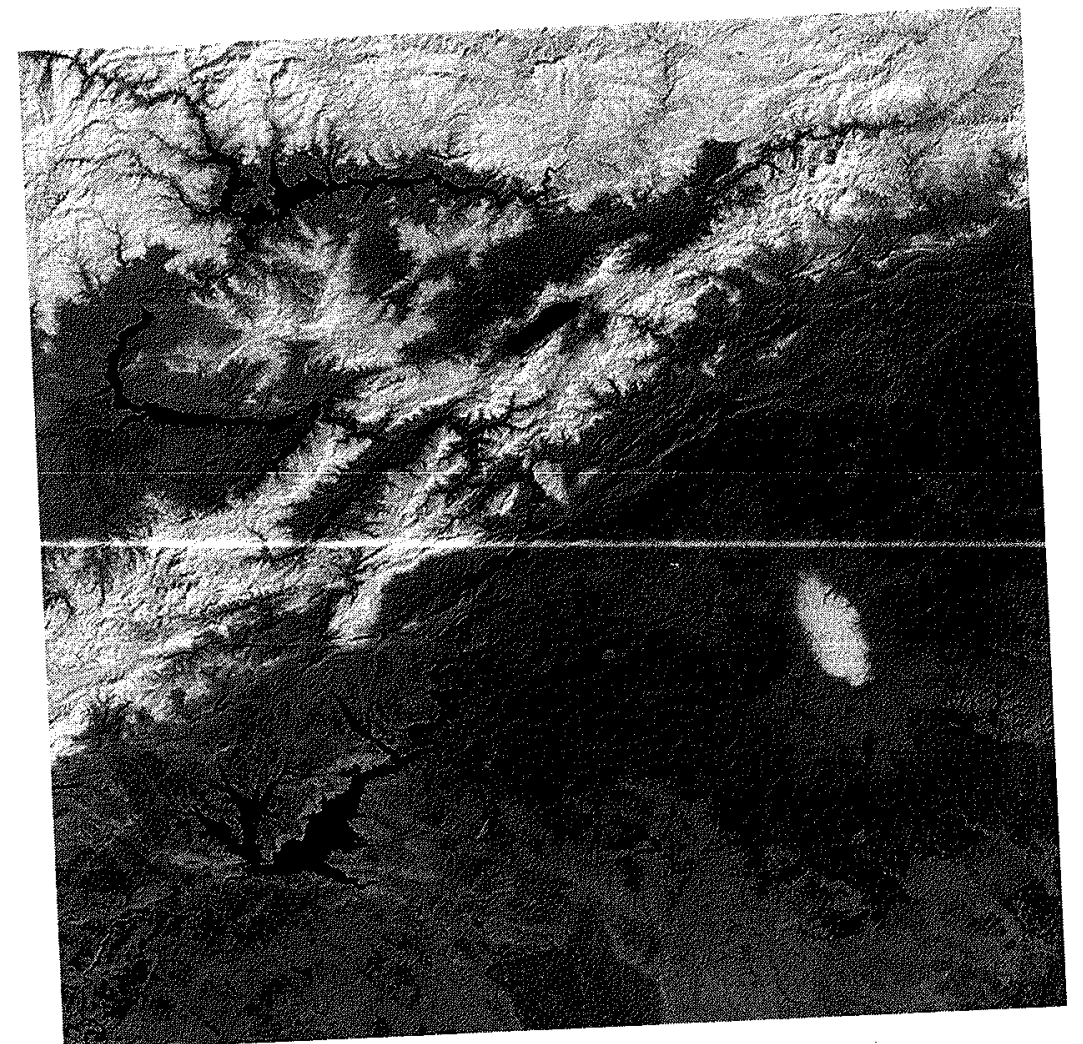

Figure 8.1. Satellite image by "Earth Snapshot Chelys," which shows the snowcapped Taurus Mountain chain in the north from which both the Tigris and Euprates Rivers originate. Notable also are the Keban, Karakaya, and Atatürk (or Karababa) Dam lakes on the Euphrates from north to south, respectively. The highland lake surrounded by snow is the seismically active Hazar Lake, which is known to be one of the sources of the Tigris. The nearly 2,000 $\mathrm{m}$ high Karacadağ Mountain stands out in the center right of the image.

basalt-rich massif near Diyarbakır, which rises to a height of $1,938 \mathrm{~m}$ (see figure 8.1; Erinç 1980). The region to the west of Karacadağ is characterized by the low-lying limestone plateaus of Urfa and Gaziantep. In contrast to gently rolling hills and plateaus found to the west, to the east of the Karacadağ Massif one finds a characteristically rugged terrain. The Diyarbakur Basin, cut diagonally-northwest to southeast-by the Tigris River, is bordered to the north by the Taurus Mountains and to the south by the Tur Abdin outcrop or the so-called Mardin-Midyat threshold, which rises to a height of 1,200-1,300 m.

Much of the mountain ranges remains unsurveyed, so it is difficult to assess highland habitation during the Chalcolithic period, yet research by Casana and Wilkinson in the Amanos Mountain Range yielded Middle and Late Chalcolithic sites such as AS 238 (Serinyol Kale) and AS 246 (Çakallı Karakol) strategically located within the Belen Pass, the route between the Mediterranean and the Amuq Plain (Casana 2003:214-15; Casana and Wilkinson 2005). Clearly, other geographically 
notable mountain passes in southeast Anatolia and beyond must have been occupied in prehistory, and future research will no doubt bring them to light.

\section{The SiXth Millennium (CAl B.C.e.)}

The beginning of the Chalcolithic in southeast Anatolia traditionally corresponds with the origin and proliferation of Halaf-type painted pottery ${ }^{1}$ in northern Mesopotamia around 6000 or $5900 \mathrm{cal}$ B.C.E. (Campbell 2007; Cruells and Nieuwenhuyse 2004; Nieuwenhuyse 2007; and see Rosenberg and Erim-Özdoğan, chapter 6, and Castro Gessner, chapter 35 in this volume). This is not to say that painted pottery was absent prior to the sixth millennium B.C.E., but it was less common than other wares. Dark-Faced Burnished Wares were the most dominant ware group in Syro-Cilicia during the Neolitihic or the Amuq A and B Phases (Balossi 2004; Braidwood and Braidwood 1960), whereas light-colored, unburnished, and often chaff tempered wares seem to characterize the pottery traditions further to the east (Campbell 1992; Cruells and Nieuwenhuyse 2004; Miyake 2007; Nieuwenhuyse 2007; Özdoğan and Özdoğan 1993; Tekin 2003, 2007; but see Nieuwenhuyse, Akkermans and van der Plicht 2010). More than a chronological shift, the widespread appearance of painted wares marks a notable change in pottery production technologies and suggests salient changes in social organization (Campbell 2007:128).

The styles, motifs, and shapes of painted Halafian pottery across all the sites in the region are easily distinguishable and identifiable. Besides obvious advantages

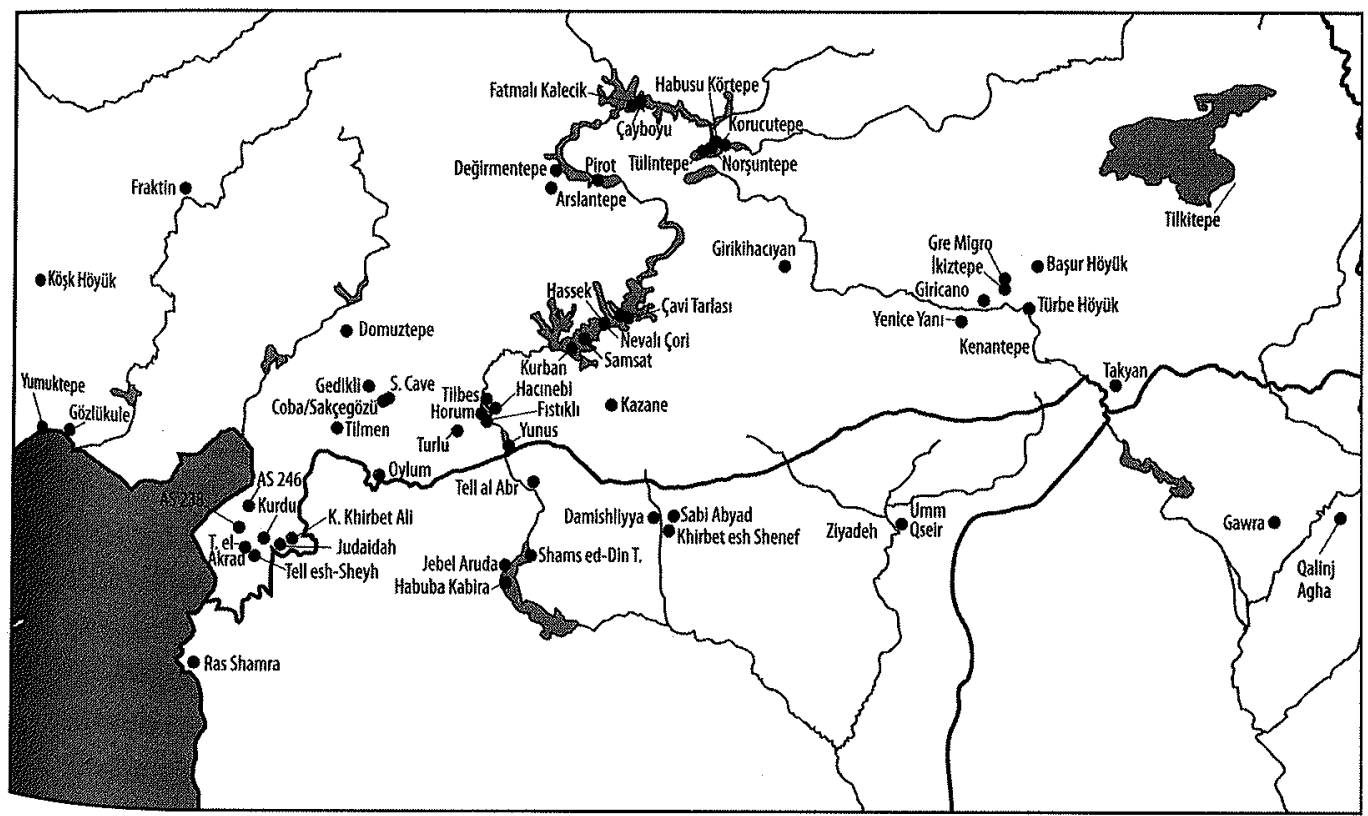

Figure 8.2. Map of sites mentioned in the text. 
for archaeologists, this pottery type bears the drawback of becoming pigeonholed into a culture group that has been described as being remarkably homogenous (Redman 1978; see Castro Gessner, chapter 35 in this volume, for additional discussion on this topic). In addition to distinctively painted pottery, Halafian cultural elements typically (although not exclusively) include geometric stamp seals and circular buildings often with rectangular antechambers referred to as tholoi (Matthews 2003; Redman 1978; Watson 1983). Although some level of cultural overlap is indisputable, at times sites with a minor percentage of Halafian-type painted sherds among a large corpus of local wares and other local elements become engulfed in this umbrella term.

Virtually all Early Chalcolithic sites in southeast Anatolia and beyond-into the Keban area, the Lake Van region, as well as the Cilician coast-have yielded Halaf painited pottery, although ceramic percentages in many cases are drastically lower than at sites in northern Syria and Iraq. Instead, chaff/vegetal or grit tempered plain wares dominate assemblages in most sites (e.g., Algaze 1989:224ff; Bernbeck and Pollock 2003; Blaylock, French, and Summers 1990:93; Rosenberg and Toğul 1991:244; von Wickede and Herbordt 1988:20; Watson and LeBlanc 1990; Woolley 1934:151). Unfortunately, the disproportional focus on decorated ceramics has led to an underrepresentation of unpainted wares in publications. A basic assessment of formal, functional, stylistic, or technological characteristics of local assemblages across southeast Anatolia, however, suggests considerable regional variability and little in terms of supraregional connections. Hence Halafian type wares are among the few that "unify" the diverse range of ceramic traditions in the sixth millennium B.C.E., perhaps justifying why these painted ceramics have gained so much attention (Akdeniz 2004).

Traditionally, the Halafians of northern Mesopotamia have been characterized as sedentary farmers (Watson 1983:238). However, new evidence (and the reassessment of old evidence, e.g., Pollock forthcoming) from Syrian sites like Khirbet eshShenef, Damishliyya, Umm Qseir, and possibly Shams ed-Din Tannira suggest that pastoral herding may also have been practiced and that some sixth millennium B.C.E. inhabitants followed semi-nomadic or seasonally based pastoral lifestyles centered around animal husbandry (Akkermans 1993; Akkermans and Schwartz 2003:117-21; Akkermans and Wittmann 1993; Pollock forthcoming; Seeden and Kaddour 1983; Uerpmann 1982). The idea that semi-nomadic populations were on the move and in constant contact and communication with sedentary sites and their residents provides a mechanism through which Halafian material elements and ideas became distributed across distant regions.

Recently, researchers have proposed that a nomadic or transhumant lifestyle may also be the case for contemporaneous sites in southeast Anatolia as well. This has been argued for Fistıklı Höyük (Bernbeck and Pollock 2003) and more recently for Çavi Tarlası (Pollock forthcoming). At Yunus (Carchemish) the "superimposed ... temporary kilns" (Woolley 1934:149) excavated by Woolley are quite clearly tholoi, probably also representing seasonal occupation. In fact, Woolley recognizes their short-term nature and suggests that they "may well be separated by months rather than years" (1934:149). One wonders, moreover, whether the frequent incidences of 
abandonment and reoccupation at Girikihaciyan could similarly be considered evidence for short seasonal occupation (Watson and LeBlanc 1990). Tholoi of comparable construction and proportions were found at Kurban Höyük (Marfoe and Ingraham 1990:25-28), Tell Turlu (Breniquet 1987, 1991), and at Nevalı Çori (Mellink 1991:127-28), although more detailed analysis of the architecture and stratigraphy as well as faunal/seasonality studies must be done for all the above-mentioned sites to assess whether some of their inhabitants were indeed (semi-)nomadic (see Castro Gessner, chapter 35 in this volume).

In addition to small seasonal campsites arguably for transhumant groups, the Early Chalcolithic in southeast Anatolia has yielded new evidence for settlements that clearly do not conform to this model. The region harbors a few sites with Halaf affiliation of previously unheard-of sizes, ranging between ten and twenty hectares, including Takyan Höyük (twelve hectares), Kazane Höyük (twenty hectares), Domuztepe (twenty hectares), Tell Kurdu (twelve to fifteen hectares), and possibly Samsat (Algaze 1989:229; Algaze et al. 1991; Bernbeck, Pollock, and Coursey 1999; Blaylock, French, and Summers 1990:89; Campbell et al. 1999; Carter, Campbell, and Gauld 2003; Özbal, Gerritsen, and Yener 2003; Özbal et al. 2004; Yener et al. $2000 a, 2000 b$ ). At Domuztepe, the excavators have demonstrated occupation across the whole twenty-hectare site (Campbell et al. 1999), but for the other settlements it must still be established what proportion was occupied simultaneously.

Nonetheless, these settlements stand out as being substantially larger than most other contemporaneous sites in northern Mesopotamia and beyond; they may, in fact, represent regional centers in a two- or three-tiered settlement hierarchy. While Takyan Höyük awaits excavation (Algaze et al. 1991:195; Kozbe 2006, 2007), Kazane, Domuztepe, and Tell Kurdu, investigated in recent years, have yielded evidence that is bringing new perspectives to how this period and the Halafian connections can be interpreted. Much information comes from Domuztepe, where excavations have been continuing for more than a decade. Research has yielded a "Death Pit" in which disarticulated and butchered bones of at least thirty-eight individuals mixed in with faunal remains were found (Kansa and Campbell 2002; Kansa et al. 2009). The disproportionally high percentage of cattle bones in the Death Pit indicates that this species may have carried special importance. Bucranium-adorned ceramics have long been viewed as a signature characteristic of the Halaf period, but the discovery of cattle in ritual contexts as at Domuztepe brings their probable ceremonial attributes to the fore. Cattle also appear to have special significance at other large excavated sixth millennium B.c.E. sites such as Kazane Höyük and Tell Kurdu. At the former site, a cache of over fiftysix cattle astragali (McCarty 2009) and at the latter, the discovery of a minimum number of five cows in what appears to be a refuse concentration (R. Özbal 2006) as well as caches of bovid horn-cores in liminal locales (Özbal et al. 2004) may indicate that cattle were connected to ritual practices and/or feasts. Though few of the large sixth millennium B.C.E. sites have been extensively excavated, this evidence suggests that different worldviews or subsistence strategies may have prevailed at these settlements than were at the smaller seasonally occupied sites. One 
interesting question worth researching is whether such concentrations of cattle bones are present also in smaller sites and to assess whether this species carried comparable significance. It is well known that in southwest Asia transhumant populations today are often sheep and goat herders (Tapper 1979:53-56; e.g., Barth 1953, 1965; Ehmann 1975:59-64; Irons 1972, 1974, 1975; also see Arbuckle 2006). In the Late Neolithic levels at the small site of Sabi Abyad, which yielded convincing evidence for (semi-)nomadism, for example, sheep/goat comprises 70 percent of the faunal remains (Cavallo 1996:477).

The broad exposures yielded by the excavations at Domuztepe also bring insights to aspects of community organization. The excavators propose that the settlement may have been divided into different quarters or wards by intentionally laid and maintained diches, requiring us to reconceptualize how we envision intrasite dynamics at this time (Carter and Campbell 2008:124). Perhaps most surprising has been a vessel with an image of gabled-roofed buildings (Carter and Campbell 2008:125). Carter and Campbell have identified a roughly contemporaneous structural parallel on a seal from Arpachiyah (Mallowan and Rose 1935:fig. 51:4) suggesting that this architectural tradition may extend far beyond the Maraş Plain. Architecture considered unusual for the Halaf period was also encountered at the Amuq $\mathrm{C}$ levels of Tell Kurdu where rectangular buildings were discovered aligned along streets built in an agglutinative style typical of Anatolian settlements (figure 8.3; Özbal et al. 2004; R. Özbal 2006).

Overall, these sites located in modern-day Turkey, far from what has traditionally been viewed as the Halafian "heartland," are interesting because they add depth and variability to the Halaf period, which until recently has been viewed as a static cultural whole. Moreover, the fusion and amalgamation of local and Halaf cultural styles has brought many insights toward understanding the intricate dynamics of the sixth millennium B.C.E. in northern Mesopotamia and southeastern Anatolia.

Toward the end of the sixth millennium B.C.E., Ubaid type pottery begins to appear across sites in northern Mesopotamia (Evin 1995:15). Often referred to as the Halaf-Ubaid Transitional (HUT) Phase (Breniquet 1996; Campbell 2007; Copeland 1979:261; Davidson 1977; Davidson and Watkins 1981; Mallowan 1946), this rather short period is usually included either within Halaf or Ubaid chronologies and is poorly defined. However, when we look at the available data beyond northern Iraq, where Halafian or Ubaid painted ceramics tend to capture most interest, we are able to identify pottery traditions that exemplify this phase of transition.

For the northern Levant and beyond, but best known at sites like Tell Kurdu (Amuq D) and Ras Shamra (Phase IV B-A), the HUT is typified by characteristic types of surface treatments like red-wash ware (Leenders 1989) and shapes like bow rim vessels (Davidson 1977; Davidson and Watkins 1981:fig. 3). A similar instance where the assemblage is not overwhelmed by the more alluring Halafian pottery and other local ceramic traditions gain importance can be found in the Keban area. This is a unique region that amalgamates both traditions that swept east-west across central and eastern Anatolia as well as north Mesopotamian traditions from the south. Here sites spanning this phase such as Korucutepe, Habusu Körtepe, 


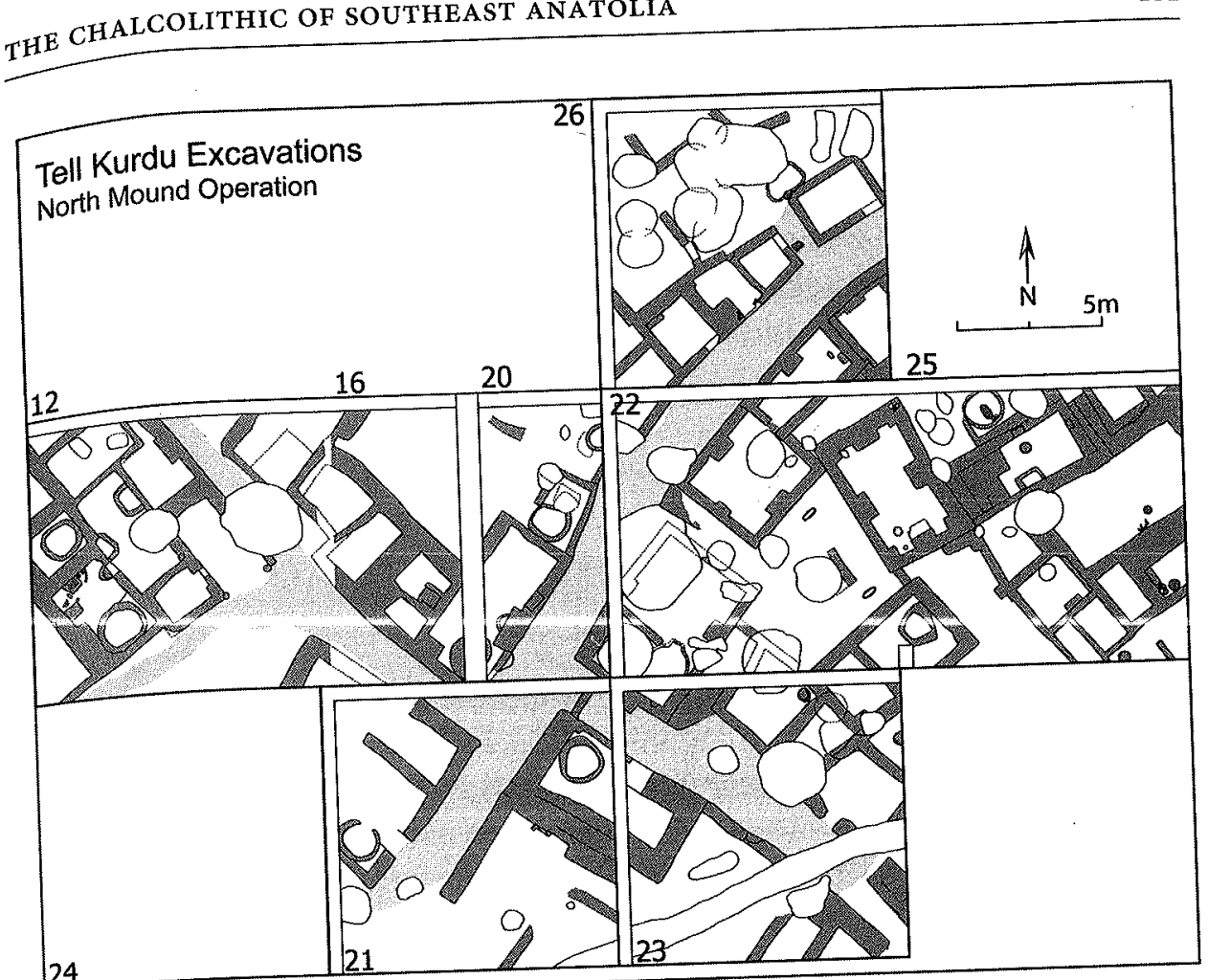

Figure 8.3. Settlement plan of the Amuq C levels at Tell Kurdu (after Özbal 20o6:fig. 1.3).

Norşuntepe, and Tülintepe yielded examples of Graphite or Mica-Slipped Ware (MSW) (Arsebük 1979; Esin 1993; Gülçur 2000; Hauptmann 1976; van Loon 1978; Whallon 1979). Esin classifies MSW, often decorated in relief, as a "local fabric in the Keban region which did not reach south of the Plain of Malatya" (1993:106). The tradition of plastic decoration found in the Keban region at this time appears to be akin to the Chalcolithic sites in central Anatolia.

By far the best known and most thoroughly excavated site that spans this period is Tülintepe, in the Altınova Plain, where excavations were able to expose over $2,000 \mathrm{~m}^{2}$ of deposits (figure 8.4). Large proportions of a village, which at its maximum extent would have been comprised of approximately thirty-five houses, were uncovered (Arsebük 1983). Rectangular mudbrick buildings, each with a large living space surrounded by depots, entry rooms, or oven spaces, were identified (Özbaşaran 1992). Although the houses are free-standing, the need for streets, as evident in Phase 2, suggests that in a more mature and circumscribed phase, the architectural set-up could eventually have developed into the agglutinative plan typical of Anatolian settlements (Steadman 200o). Halafian-like and Ubaid type painted ceramics are rare at Tülintepe, but they exceed the percentages from other contemporaneous sites in the Altınova Plain (Özbaşaran 1992).

Based on Garstang's excavations at Mersin Yumuktepe, Level XVI has typically been assigned to the transition from the Halaf to the Ubaid period (Caneva 2004; 


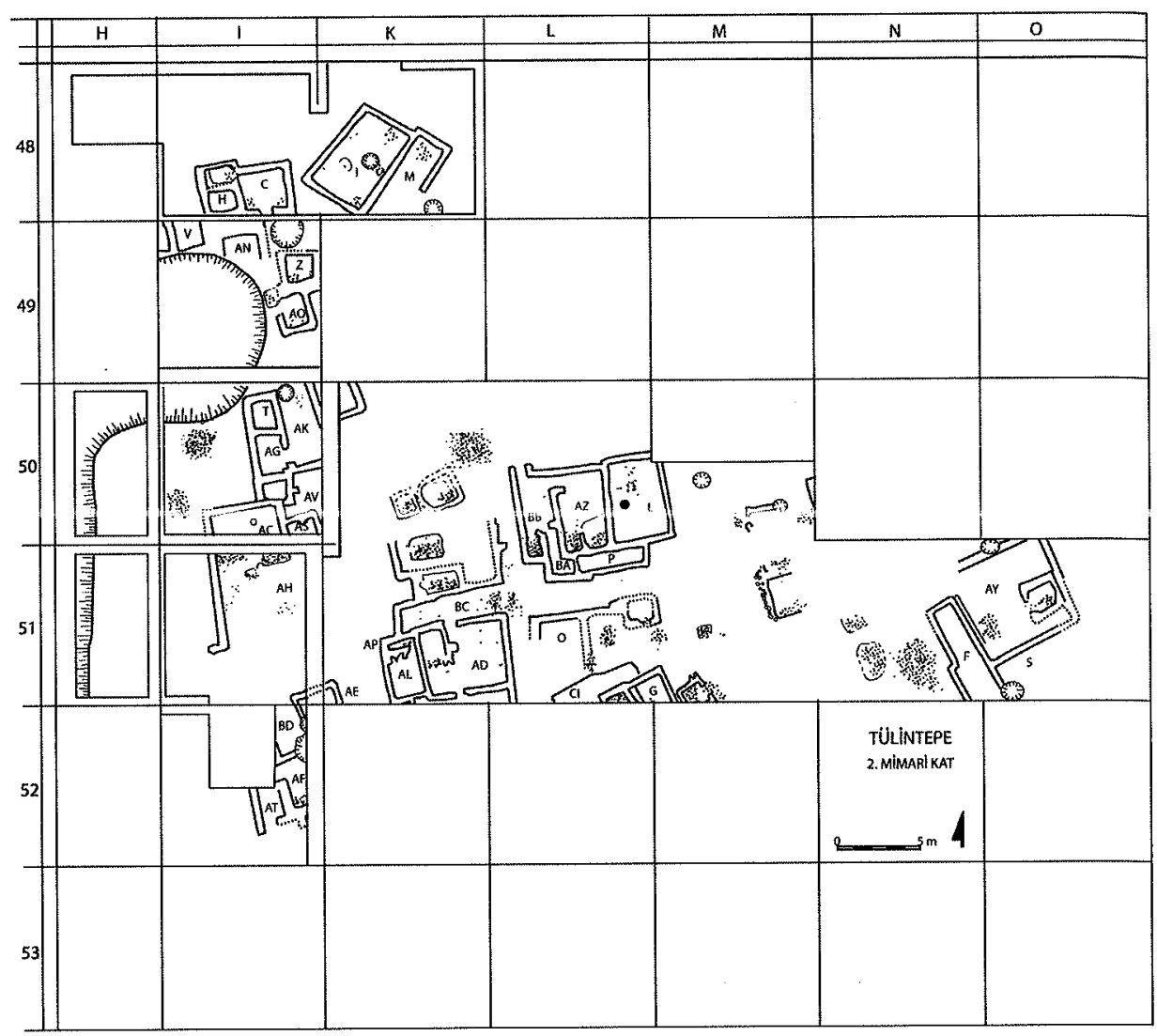

Figure 8.4. Settlement plan of Tülintepe Level 2 (after Özbaşaran 1992:fig. 22).

Garstang 1953:141-42). However, given that one finds Ubaid-like motifs already in Levels XIX-XVII (Braidwood and Braidwood 1960:509) it may prove useful to reanalyze a larger corpus of both the plain and painted wares of Chalcolithic Yumuktepe. ${ }^{2}$ In terms of architecture, renewed excavations of Mersin Level XVI and the discovery of complex terracing activities have shown that the exposed structures of this phase show considerable variability (Caneva 2004; see also Garstang 1953:fig. 79; Garstang and Goldman 1947:379). Nonetheless, the overall plan of arrangement around an open courtyard is also found at the contemporaneous levels of not too distant Köşk Höyük Level 1, located near the Niğde Pass (Arbuckle 2006:fig. 2.13; and see Schoop, chapter 7 in this volume). Ceramics found at Mersin that have been interpreted as imitation Halafian wares (Davidson 1977) are missing from Koşk Höyük, but relief decoration (like that described for Tülintepe) is a common form of vessel adornment (Öztan 2002).

Few other sites spanning the HUT have been excavated in southeastern Turkey. Although represented at Tell Kurdu during the Amuq D phase, perhaps in Level A at Korucutepe, and Level XIV at Pirot Höyük, too little is known about the period in question at these sites. Sites like Domuztepe end just at this critical period and 
cannot be used to further define this amorphous transitional phase (Campbell 2007; Campbell and Fletcher 2010). However, precisely because this period straddles a transient and short-lived window in which neither Halaf nor Ubaid influences were particularly strong, further research could prove promising for highlighting local chronologies, wares, and styles. This may ultimately shift the emphasis to the local, rather than to one of the two dominant cultures, which dictate the Chalcolithic of eastern and southeastern Anatolia and Syro-Cilicia.

\section{The Fifth Millennium (Cal B.C.e.)}

North Mesopotamian Ubaid influences in southeast Anatolia intensify in the fifth millennium B.C.E. However, our information on social, political, and economic issues and daily life as well as the significant question of how Ubaid influences change these aspects is limited because this is the most poorly investigated phase of the Chalcolithic period in this region. Painted Ubaid wares are known to have reached far beyond the north Mesopotamian steppe and foothills and have been discovered as far north as Kayseri and the Elbistan-Afşin Plain (Brown 1967; T. Özgüç 1956), as far west as Mersin (Akkermans 1988:110; Garstang 1943:8), and as far east as the area now explored in the Upper Tigris (Algaze 1989; Algaze et al. 1991; Bernbeck, Costello, and Unnal 2004; Kozbe 2006, 2007; Ozan 2009; Parker et al. 2008, 2009; Sağlamtimur and Ozan 2007).

Compared with the previous Halaf phase, in the Ubaid period pottery production becomes significantly more efficiency-oriented. Vessels are painted with less care and produced on a slow wheel, but the ceramics remain as distinctive and easy to identify as before (Perkins 1949; Redman 1978). Much of our knowledge of the Ubaid period in Turkey is based on this recognizable pottery style, as we have little evidence on architecture and associated finds. Ubaid pottery was found, for example, near İslahiye in the Plain of Sakçegözü at Coba Höyük and the nearby cave site, at Gedikli as well as at Tilmen Höyük (U. B. Alkım 1962; H. Alkım 1979; Alkım and Alkım 1966; du Plat Taylor, Williams, and Waechter 1950; Waechter, Göğüs, and Williams 1951). Yet the related architectural fragments detected in the plain, such as the wattle and daub wall remnants found in Coba Level IV and Gedikli IVa, were too piecemeal to make sense of (du Plat Taylor, Williams, and Waechter 1950; U. B. Alkım 1968:21-22). In the north, sites in the Altınova Plain like Korucutepe, Fatmal1Kalecik, Norşuntepe, and Tülintepe yielded small percentages of Ubaid-like ceramics but no associated architecture (Esin and Arsebük 1974, 1982; Gülçur 2000; Hauptmann 1982; Özbaşaran 1992; van Loon 1978; Wright and Whallon 1998:780). Similarly, Ubaid wares were discovered in excavations and surveys in the Kilis, Adıyaman, Birecik, and Harran Plains (Blaylock 1998; Blaylock, French, and Summers 1990; Fuensanta et al. 2007; Özgen, Helwing, and Engin 2002; Özgen et al. 2003; Summers and French 1992; Yardımc1 1993, 2001:46-47), but the only site 
yielding any substantial architecture was a single-phase mound excavated by the Tilbes Project (Fuensanta et al. 2006).

Most recently, with the upcoming Tigris dams, intensified research in Diyarbakır, Batman, Siirt, and Şırnak have determined a rich Ubaid presence along the Upper Tigris and its tributaries (Algaze 1989; Algaze et al. 1991; Bernbeck, Costello, and Ünal 2004; Kozbe 2007, 2008; Ozan 2009; Parker et al. 2008, 2009; Sağlamtimur and Ozan 2007), yet Kenan Tepe remains the sole site to have yielded extensive architecture (Parker et al. 2008, 2009). Further west, excavations or detailed ceramic analyses have been conducted at many Cilician Syro-Anatolian sites like Mersin, Tarsus Gözlükule, and a number of Amuq settlements including Tell Kurdu, Judaidah, Tell esh-Sheikh, Tabara el-Akrad, and Karaca Khirbet Ali (Braidwood and Braidwood 1960; French 198; Garstang 1953; Goldman 1956; Hood 1951; R. Özbal 2006; Özbal et al. 2004; Woolley 1959:5-6; Yener et al. 2000a, 200ob). However, because the results of the Tell esh-Sheikh excavations still await publication (French 1985; Woolley 1959), the only architecture to speak of in this northwestern sector of the "Ubaid expansion" comes from Tell Kurdu and Mersin XV. Değirmentepe on the Malatya Plain is perhaps an exception with its large corpus of Ubaid tripartite structures (Esin 1983, 1985, 1989, 1993, 1994, 1996; Esin and Harmankaya 1986, 1987, 1988), but excavation of the fifth millennium levels at not-toodistant Pirot Höyük yielded hardly any discernible architecture (Akdeniz 2004; Karaca 1985). Overall, in other words, in southeast and eastern Anatolia our knowledge of Middle Chalcolithic occupation, beyond ceramics, is based on a mere handful of sites.

By the first half of the fifth millennium B.C.E., Ubaid ceramics comprised a notable part of pottery assemblages in northern Mesopotamia across a broad eastwest arc (Campbell 2007; Hammade and Yamazaki 1995, 2006:431; Parker et al. 2008; Yener et al. 2000a). This phase is sometimes referred to as the Ubaid 3 phase based on the southern Mesopotamian chronology. Sites west of the Euphrates like Tell Kurdu (Diebold 2000; Edens and Yener 2000), Mersin (Garstang 1953), and possibly the Sakçegözü Cave Site (French and Summers 1988) have yielded ceramics that could be identified as early northern Ubaid. Research in Turkey east of the Euphrates has been much less intensive, but radiocarbon dates from Kenantepe indicate that the earliest levels of Ubaid occupation here predate 4700 cal B.C.E. (Campbell 2007; Parker et al. 2008). During the early northern Ubaid painted ceramic percentages tended to be relatively high. The Ubaid-related levels at Tell Kurdu, for example, show an "overwhelmingly Ubaid complexion" (Braidwood and Braidwood 1960:511) in the Amuq E Phase, when 45 percent of the pottery is painted in the northern Ubaid style (Diebold 2000; R. Özbal 2010).

Architecture shows considerable variability in this region at this time. At Mersin, small rectangular rooms with peculiar rounded corners were identified in Level XV (Garstang 1953:156). Further east, in the Amuq, the architecture shows more parallels with northern Ubaid sites. Particularly notable is a grill-like structure, for example, discovered at Tell Kurdu (R. Özbal 2010:298), resembling ones from Tell Ziyadeh Level 1 (Arzt 2001:fig. 2.1); Tepe Gawra Levels XV, XVA, and XVI (Tobler 
1950:XV-XVII); and Tell al-'Abr Level 7 (Hammade and Koike 1992:fig. 12; Hammade and Yamazaki 2006). Such structures are assumed to have been used as granaries or storage structures (Akkermans and Schwartz 2003:166). Although not grill-planned, excavations of roughly contemporaneous levels at Kenan Tepe near Bismil also yielded many cell-planned structures most probably used for storage (Parker et al. 2008:107).

Radiocarbon dates for the following phase, often labeled the Ubaid 4, indicate that it begins around the mid-fifth millennium B.C.E. and ends roughly around 4300 cal B.C.E. (Akkermans and Schwartz 2003; Balossi Restelli 2008; Rothman 2001a; Wright and Rupley 2001; Yakar, chapter 4 in this volume). The far northern reaches of the Euphrates around Malatya and Elazı̆g also contribute to our knowledge of occupation at this time. Flint-scraped Coba bowls, considered the hallmark of the Terminal Ubaid, are widespread throughout northern Mesopotamia and are found as far east as Muş (Russell 1980) and as far west as the Elbistan Plain (Brown 1967).

Northern Mesopotamia has few examples of tripartite structures. They are best known from Tepe Gawra in northern Iraq and Değirmentepe near Malatya. At Kenan Tepe's later Ubaid levels, a residential complex called "Ubaid Structure 4" was uncovered (Parker et al. 2009). There appears to be a central courtyard flanked by rows of side rooms to the north and east. Although it cannot currently be ascertained, Parker and colleagues (2009:90) mention the high likelihood of a parallel flank along the western wall making the structure tripartite. Finally, Fuensanta et al. (2006:446) report that prior to flooding by Birecik Lake, the presence of an Ubaid tripartite building as well as two bipartite ones were exposed in a $1,300 \mathrm{~m}^{2}$ area, as part of the Tilbes Project. The structure has been assigned to the Terminal Ubaid phase, however the analysis of the ceramics currently awaits publication (Fuensanta et al. 2006).

Referred to as the Ubaid "type-site" in Turkey, Değirmentepe in Malatya combines typically Ubaid tripartite architectural structures with a characteristically Anatolian agglutinative plan (Gürdil 2010; Stein and Özbal 2007). Excavations yielded traces of wall painting and evidence for various craft activities like metal production and lithic knapping (Esin and Harmankaya 1988). Each residential structure appears to have encapsulated ritual aspects as indicated by offering podia, altars, and burials as well as nearby pits containing ash and sacrificial offerings, uniquely mixing northern and southern cultural styles (Esin and Harmankaya 1988:92-93, 104-5; Gürdil 2010; Helwing 2003:68; Stein and Özbal 2007).

Recently, an under-researched post-Ubaid phase dating to the last three centuries of the fifth millennium B.C.E., assigned to the $\mathrm{LC}_{1}$ and $\mathrm{LC} 2$ (based on the SAR chronology by Rothman 2001a) has been the topic of investigation at a number of southeast and eastern Anatolian sites (Balossi Restelli 2008). Perhaps the most complete information on this period comes from Arslantepe VIII, where excavations yielded at least two occupational phases of architecture (Balossi Restelli 2008; Balossi Restelli and Guarino 2010). Other sites that yielded similar types of ceramics include Oylum Höyük Stratum 6-2 (Özgen et al. 1999), Coba Höyük IVC (du Plat Taylor, Williams, and Waechter 1950), Norşuntepe Phases II-III (Gülçur 2000), 
Hayaz Höyük 5-4 (Thissen 1985), Korucutepe XII-XXX (van Loon 1978); Yenice Yan1 Level 4 (Kennedy 2008), and much of the prehistoric pottery from Horum Höyük (Fletcher 2007). More research is necessary to assess the exact chronological relationships between the above-mentioned settlements and how the phase differs or relates to the traditional Late Ubaid.

The ceramics in this phase show variability from site to site, yet there appears to be a close relationship between the wares from Oylum Höyük (Özgen et al. 1999), Arslantepe VIII (Balossi Restelli 2008), and Hammam et-Turkman VA-B (Akkermans 1988). This includes high percentages of flint-scraped pottery and occasionally other forms of decoration, like incised appliqué. Some shapes resemble Amuq $F$ wares even though the phase would be more accurately placed in a hiatus between Amuq E and F. Mass-produced Coba bowls continue to be dominant, in some cases comprising as much as half the assemblage (Trufelli 1994). Many regional variants of this distinctive mass-produced bowl exist (Akkermans 1988; Gülçur 2000:377; Özgen et al. 1999:41-42; Trufelli 1997). Painted Ubaid sherds are still present, though in declining numbers in most assemblages (Akkermans 1988; Gülçur 200o; Özgen et al. 1999; van Loon 1978).

Excavations at Arslantepe VIII and at Oylum Höyük Stratum 5 have yielded architecture associated with this Post-Ubaid Phase. At both sites the exposed areas include large courtyards in which craft activities took place (Balossi Restelli 2008; Özgen et al. 1999:41). The courtyard at Arslantepe was probably used for food preparation and cooking because a number of ovens, hearths, and other food processing implements were recovered. Small domestic rooms were exposed around the large open courtyard, two of which yielded in situ door sockets and thresholds (Balossi Restelli 2008).

Although the "Ubaid Expansion" and "Uruk Expansion" appear to be propelled by completely different mechanisms of transmission and dispersal (Stein and Özbal 2007), there is still much debate about how, for the former period, material cultural aspects found their way across southeast Anatolia and even beyond into the Taurus Mountains. Trade (Oates 1993; Oates and Oates 2004), colonial expansion (Esin and Harmankaya 1988; Gürdil 2005), spread of an ideology (Breniquet 1996), and the peaceful appropriation of Ubaid elements within local assemblages (Stein and Özbal 2007) are among the proposals that have been made. Further research into the understudied LC 1 or LC 2 Phases may provide insights into the local reactions to the changing foreign influences.

\section{The Fourth Millennium (CAl B.C.e.)}

The radiocarbon dates for the Post-Ubaid phase, as compiled by Balossi Restelli (2008), and for the Uruk period as researched by Wright and Rupley (2001), demonstrate that the beginnings of incipient state formation, evidence for social 
reorganization, and the formation of new political connections date to the beginning of the fourth millennium B.C.E. (Adams 1966, 1981; Frangipane 2007; Nissen 2000; Pollock 1992; Wright 2001). Although it was originally presumed that early state systems were restricted either to the southern Mesopotamian alluvium or to Uruk-influenced sites/colonies in the north, over the past few decades excavations of the precontact levels at sites like Arslantepe (Frangipane 1993, 1997a, 1997b), Hacinebi (Stein 1999, 2001, 2002), Hamoukar (Gibson et al. 2002) and Tell Brak (Oates et al. 2007) have made it clear that the indigenous societies with whom the Urukians interacted had already independently evolved into complex administrative centers (for Anatolia specifically, see Sagona and Zimansky 2009).

This section outlines some of the developments that characterize southeastern Anatolia in the fourth millennium B.C.E. Compared with the sixth and fifth millennia already described, the fourth millennium has been researched quite extensively. Because the Uruk presence in southeastern Anatolia is covered in detail elsewhere in this volume (see, e.g., chapter 37 by Rothman), and Arslantepe is one of the key sites discussed (see chapter 45 by Frangipane), this section largely confines itself to the local Late Chalcolithic and the notable changes in social, political, and economic spheres (see Foster 2009; Pearce 2008:24-32; Sagona and Zimansky 2009:144-62). All evidence for the Euphrates region points toward incipient complexity that is indigenous to the regions and settlements in question. Evidence for monumental architecture is consistently present prior to Uruk contact (Frangipane 1997b; N. Özgüç 1992; Stein 2002; Stein et al. 1998). This marks the first appearance of urban spaces and town planning at the settlement level (Frangipane 1993; Gibson et al. 1997a; 2002; Oates and Oates 1997; Oates et al. 2007; Stein et al. 1998; Ur, Karsgaard, and Oates 2007). At Hacinebi already in Level A evidence for a massive stone buttressed wall, nearly four meters in height, and monumental mudbrick platforms, were discovered (Stein et al. 1998). At Arslantepe, too, excavations yielded a large tripartite structure, clearly of public importance, with wall paintings and mudbrick column bases in Level VII, prior to any Uruk impact (Frangipane 1993, 1997a; Frangipane and Balossi 2004). Although excavations were limited, part of a fortification wall was uncovered at Samsat Level XXIV (Algaze 1993:34; Mellink 1989; N. Özgüç 1992).

Having said this, evidence suggests considerable interregional differentiation. Although the Upper Euphrates region clearly illustrates indigenous social complexity, this may not be the case for the sites in the Upper Tigris Valley, perhaps due to their relative isolation (Creekmore 2007; Foster 2009). Although further excavations may prove otherwise, public or monumental structures, town planning, and specialized production found at precontact sites in the Euphrates Valley appear to be absent from at least the site of Kenantepe in the Upper Tigris. This situation is coupled by a seeming resistance to foreign influence. Even when Uruk presence in the region is confirmed by the presence of beveled rim bowls (Algaze 1989: 244; Algaze et al. 1991; Schachner 2004; Şenyurt 2002; Velibeyoğlu, Schachner, and Schachner 2002), other evidence for Uruk influence is meager (Foster 2009). Further excavations especially at Giricano near Bismil and Başur Höyük in the 
Botan-both with comparatively more compelling evidence for Uruk connectionscould prove otherwise (Sağlamtimur 2009; Schachner 2004).

In addition to regional differences in how Uruk presence was internalized, evidence also points to variability across sites in the same region (but see Lupton 1996:20). Regional surveys suggest a two- or three-tiered settlement hierarchy, with larger towns surrounded by agricultural sites in the countryside (Algaze 1989, 1993:92-95; Algaze et al. 1991; Algaze, Breuninger, and Knudstad 1994; Lupton 1996:22-26; Özdoğan 1977; Ur 2002; Whallon 1979). Samsat in the Karababa Dam area and Arslantepe in the Malatya Plain may be considered examples of focal sites at the head of three-tiered settlement hierarchies (Frangipane 1993; Lupton 1996:53). Similarly for the Late Chalcolithic period in the Batman region, Algaze (1989:244) identifies a fow large sites that must have dominated the fourth millennium land scape B.c.e., notably İkiztepe and Gre Migro.

This variability can be extended even to the intrasite level as noted by Pearce (2008:29; see also Gibson et al. 2002; Oates et al. 2007). At Norşuntepe on the Euphrates, for example, we find larger and smaller residences within the same settlement. The architecture from Level 10 shows a road or alleyway flanked by smaller structures to the west and a larger complex to the east (Hauptmann 1976, 1982). As at Arslantepe some buildings had red and black painted walls (Hauptmann 1976). Unfortunately the exposures at Norşuntepe are too small to extrapolate too much about town planning and the details of the intrasite variability, but the density of structures suggests similarities with contemporary north Mesopotamian sites like Tepe Gawra (Rothman 2001b:397) and Qalinj Agha (Abu al-Soof 1967; Lupton 1996). Small portions of regular planned buildings were exposed in excavations in the Upper Tigris, most notably at Giricano (Schachner et al. 2002:557-58) and Kenan Tepe (Foster 2009; Parker et al. 2009).

Record-keeping artifacts such as stamp seals and seal impressions are clear indications for complex and hierarchical administrative practices (Ferioli and Fiandra 1983; Pittman 2001; Reichel 2002; Wright and Johnson 1975). Used as ways to monitor individual or family property and ownership, stamp seals and sealings are found in increasingly larger numbers in southeast Anatolia by the fourth millennium B.C.E. and demonstrate that status differences were becoming more pronounced (Frangipane 1993, 1994; Hauptmann 1976; Pittman 1996, 1999, 2001; Schachner 2004; Stein 2001:274-75; see also Pearce 2008:28). Other administrative artifacts like bullae with seal impressions make their first appearance in this region during the Late Chalcolithic (Hauptmann 1976; Pittman 2001:416; Stein et al. 1998:148; Wright 2001:141-42).

Evidence exhibits specialization in crafts and the apparent need for efficiency in ceramic manufacture. This is a development that began in the fifth millennium B.C.E., as already described. Ceramics in the Late Chalcolithic gradually show increasing signs of low-cost production (Pearce 2000:122, 2008:26; Trufelli 1994). Elaborate painting and decoration of previous horizons is conspicuously missing. Chaff tempering, standardization, and low temperature firings may be characterized as strategies to cut costs (Akkermans 1988; Pearce 2008; Trufelli 1994). The 
discovery of potters' marks extensively across northern Mesopotamia and beyond at this time indicates a preference for mass firings (Lupton 1996:20; Pearce 2008:26; Stein et al. 1998). The fact that these characteristics are consistently found at all sites indicates supraregional transformations in the social and technological realms of ceramic production processes. However, only a few ceramic shapes show crossregional similarities. As Lupton (1996:20) puts it, "the pre-contact period in north Mesopotamia and southeast Anatolia comprised a number of distinct regional entities, which were interconnected, at one level, in a basic technological sense, and at another level through a limited range of characteristic types." Yet a great majority of the ceramics in each region is "idiosyncratic to that region alone" (Lupton 1996:20; Pearce 2000:121-22). Similarly, evidence points to the increased production of other crafts in the fourth millennium B.C.P. like the manufacture of metal tools (de Jesus 1980; Esin 1976; Hauptmann 1976; H. Özbal 1996, 1997; H. Özbal, Adriens, and Earl 1999; Palmieri, Sertok, and Chernykh 1993; Stein 2001:277; Yener 2000; and see Muhly, chapter 39 in this volume) and textiles (Keith 1998).

Metal artifacts in graves have been used to signify a growing élite class at some sites (Yener 2000). At Hacinebi, for example, excavations yielded jar burials of infants and small children, one of which was buried with a copper ring, two silver earrings, and a miniature ceramic vessel (Stein 2001:273; Stein et al. 1996:96). Silver is extremely rare in this period, and its discovery associated with the infant may indicate ascribed status (Stein 2001:274). Child burials with precious gifts were also discovered in northern Mesopotamia at Tepe Gawra and Qalinj Agha (Abu al-Soof 1967:71-72; Rothman 20o1b:393). Other sites like Kenan Tepe lack evidence for an élite presence (Foster 2009).

The second half of the fourth millennium B.c.E. was a time of intense change and adjustment for the inhabitants of southeast Anatolia and northern Mesopotamia as southern Mesopotamians settled across or interacted with settlements in the Upper Euphrates, Upper Tigris, and beyond in their quest to obtain raw materials. A fascinating aspect of this interaction between the local and the Uruk is the varied manner in which relations played out at different sites. Whereas some sites appear to have functioned as stations or outposts for Urukians, others were places in which Uruk inhabitants set up residence and created foreign neighborhoods within or near a preexisting local settlement (Algaze 1993). At the same time, however, there are also Late Chalcolithic sites where little Uruk presence is seen (Foster 20o9; Steadman 1996).

Hassek Höyük in the Karababa Dam area, has been interpreted as an Uruk "station" established to control the access of goods (Behm-Blancke et al. 1984:40). This has been based on the fact that excavations yielded southern Mesopotamian type courtyard buildings built directly on virgin soil, not unlike those from Jebel Aruda and Habuba Kabira Süd (Behm-Blancke et al. 1984; Sürenhagen 1986). Other architectural features like wallcones similar to those used to adorn and protect walls of public structures in the southern alluvium (see Lloyd and Safar 1943), and the discovery of bones of swordfish native to the Persian Gulf (Lupton 1996:60-61), leave little doubt of a strong Uruk presence in the area. Yet research by Helwing has aptly 
demonstrated that many Uruk style artifacts and ceramics from Hassek Höyük may in fact have local undertones (Helwing 1999, 2002).

Recently Sağlamtimur (2009) conducted excavations at Başur Höyük, which he describes as a "station" along the Botan tributary of the Upper Tigris, near Sirt. A series of depot rooms, some with walls as wide as $150 \mathrm{~cm}$, containing stores of lentils, barley, and wheat as well as large quantities of beveled-rim bowls were discovered. Sağlamtimur believes that these structures may have been part of a public administrative complex, but it is still too early to make a conclusive assessment of the settlement's function in the greater Uruk Expansion.

Our best knowledge of an Uruk "enclave" comes from Hacınebi Tepe located on the Euphrates in Birecik (Stein 1999, see also Young 1986 for a description of Godin Tcpe, another "enclave"). The Late Chalcolithic residents living in Hacinebi Phase A began sharing the site with southerners by Phase B2, dating to around 3400 cal B.C.E. Located at the northeast side of the settlement in their own quarter, the Urukians showed different preferences in their diet (Stein 1999:145-46; Stein and Nicola 1996), the ways in which they butchered meat (Stein 1999), and their lithic tool manufacturing technologies (Edens 1996, 1997, 1999). In Phase B2, wheelmade and mineral tempered Uruk-type ceramics and typical Uruk vessel shapes like beveled-rim bowls and spouted jars inundate the ceramic assemblage (Pearce 2000, 2008).

Contrasting starkly with sites in which southern Mesopotamian presence is strong, one also finds, as mentioned above, local Late Chalcolithic settlements dating to the second half of the fourth millennium B.C.E., which surprisingly appear not to have been influenced by Uruk colonists. One such site is Kenan Tepe located in the Upper Tigris region (Parker et al. 2008). Another area lacking Uruk influences is Cilicia. This may be a result of the distance involved and the region's "isolationist" policy (Steadman 1996). For Kenan Tepe, it is possible that the inhabitants of this village settlement may not have reached the type of emergent complexity that other settlements had (Foster 2009). If so, this would have been an obstacle in adopting the urban Uruk ways of life. Indeed, research by Foster (2009) shows that the excavated portions of the settlement lack the types of craft facilities discovered at other Late Chalcolithic sites. Although excavations yielded a great number of cooking ovens, no kilns or smelting furnaces were discovered. The areas exposed are naturally limited, but the current data indicate a lack of burials with ascribed status, and intrasite variability among households (Foster 2009).

Kenan Tepe offers the potential to explore diachronic change in the Late Chalcolithic. Perhaps most remarkable is an increasing reliance on pig husbandry in the Late Chalcolithic 5 Period when an Uruk presence would most strongly have been felt in southeast Anatolia. Foster (2009) argues that a reliance on pigs is a "riskabatement strategy" at times of economic instability or influx and further implies that the Kenan Tepe residents may have been asserting "independence" during this period when the political and economic repercussions of Uruk presence in the area-like at nearby Giricano (see Schachner 2003, 2004; Schachner et al. 2002)were undoubtedly felt. Her argument stems from the idea that pig rearing is 
relatively efficient and may have been preferred by small detached households at times of economic uncertainty, given the abundant offspring pigs yield and the limited time it takes them to reach maturity. Overall, the intensified excavations

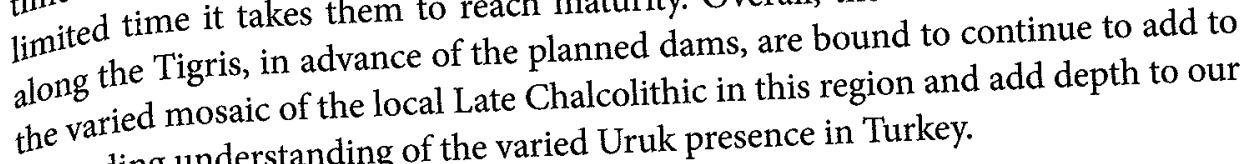
expanding understanding of the varied Uruk presence in Turkey.

\section{Conclusion}

Overall, the developments taking place in southeast Anatolia during the three miliennia covered in this chapter closely parallel those in northern Mesopotamia. Yet the perspectives provided by the research conducted in modern-day Turkey significantly enrich the picture. For example, the discovery that southeast Anatolia houses exceptionally large sixth millennium B.C.E. sites with Halafian-like affinities is relatively recent but has the potential to stir and reshape static ideas about the Halaf
period. Detailed, long period. Detailed, long-term excavations like those at Domuztepe broaden our
understanding of how such large sixth millennium B.C.E. settlements may have functioned and provide new insights into intrasettlement dynamics.

Our knowledge of the fifth millennium B.c.в. in southeast Anatolia, especially in aspects of architecture and settlement organization, is less comprehensive. Değirmentepe has often been labeled as the Ubaid type-site in Anatolia. There is little doubt that this is a truly exceptional settlement, but the focus on its Ubaidness has meant that many of its local aspects, like a great majority of its ceramics, have consequently been understudied. Our aim for this period should be to analyze sites, characterize local elements, gain insights into lifestyles, understand settlement dynamics, and define what constitutes a local community for the specific region studied. Only then can further research not only discover how local Anatolian aspects combined with Ubaid characteristics but also clarify questions on the expansionary dynamics of Ubaidians or Ubaid elements to the region in question. Perhaps another way to investigate the fifth millennium B.c.E. would be to focus on the transitional phases that precede and follow the Ubaid period (such as the HUT or the Post-Ubaid) because less well-defined intervening stages may in fact carry less archaeological and scholarly baggage.

Research over the past few decades in southeastern Anatolia, especially the Upper Euphrates and environs at sites like Hacinebi and Arslantepe, has transformed our understanding of the fourth millennium B.C.E. significantly. There is now little doubt that local settlements in the Taurus piedmont zone of southeast Anatolia had ample evidence for a high level of social complexity even before contact with Uruk polities. Yet now the salvage excavations along the Tigris have set the scene for investigations of the fourth millennium B.C.E. in a new region. Although the idea that each site was affected differently by the Uruk phenomenon 
is not new, the discovery of Late Chalcolithic levels at Kenan Tepe in the Upper Tigris Valley, a site devoid of Uruk elements all together, triggers new questions and possibilities toward further understanding Mesopotamian colonization at this time.

\section{NOTES}

This chapter was completed at the Prehistory Section of the Department of Archaeology at Istanbul University through post-doctoral funding provided by The Turkish Academy of Sciences (TÜBA). Many thanks go to the editors of this volume as well as Andy Creekmore and Fokke Gerritsen for their insightful comments on this text. I am grateful to Francesca Balossi Restelli, Ali Ozan, and Stuart Campbell, who kindly shared their unpublished articles with me. I would also like to thank Güven Arsebük and Mihriban Özbaşaran for allowing me to include a plan of Tülintepe in figure 8.4.

1. Recently, as new absolute dates have come to light and researchers have recognized that Halafian-type pottery and architecture have roots going back well into the Neolithic, many have begun to categorize the Halaf period as "Late Neolithic", rather than "Early Chalcolithic" (Akkermans and Schwartz 2003; Campbell 2007; Cruells and Nieuwenhuyse 2004).

2. Another site with levels spanning this period where the ceramics deserve thorough reanalysis is Tell esh-Sheikh (Woolley 1959). The published ceramics do show some overlap with Yumuktepe XIX-XIII but too little is known to further extrapolate.

\section{REFERENCES}

Abu al-Soof, Behnam. 1967. More Soundings at Qalinj Agha (Erbil). Sumer 23: 69-74. Adams, Robert M. 1966. The Evolution of Urban Society. Chicago: Aldine.

1981. Heartland of Cities. Chicago: University of Chicago Press.

Akdeniz, Engin. 2004. Halaf ve Obeyd Kültürleri Üzerine Bazı Gözlemler ve Pirot Höyüğün Halaf ve Obeyd Boyalı Çanak Çömleği. Anadolu Araştırmaları 17.2: 1-48.

Akkermans, Peter M. M. G. 1988. An Updated Chronology for the Northern Ubaid and

Late Chalcolithic Periods in Syria: New Evidence from Tell Hamman et-Turkman. Iraq 50: $109-45$.

-1993. Villages in the Steppe: Later Neolithic Settlement and Subsistence in the Balikh

Valley, Northern Syria. Archaeological Series 5. Ann Arbor, Mich.: International

Monographs in Prehistory.

Aksoy, Behin and Steven Diamant. 1973. Cayboyu 1970-71. Anatolian Studies 23: 97-108.

Algaze, Guillermo. 1989. A New Frontier: First Results of the Tigris-Euphrates

Archaeological Reconnaissance Project, 1988. Journal of Near Eastern Studies 48.4: 241-81.

1993. The Uruk World System. The Dynamics of Expansion of Early Mesopotamian

Civilization. Chicago: University of Chicago Press. 
Algaze, Guillermo, Ray Breuninger, and James Knudstad. 1994. The Tigris-Euphrates Archaeological Reconnaissance Project: Final Report of the Birecik and Carchemish Dam Survey Areas. Anatolica 20: 1-71.

Algaze, Guillermo, Ray Brueninger, Chris Lightfoot, and Michael Rosenberg. 1991. The Tigris-Euphrates Archaeological Reconnaissance Project: A Preliminary Report of the 1989-1990 Seasons. Anatolica 17: 175-240.

Alkım, Handan. 1979. Gedikli (Karahüyük) Çanak Çömleğine Toplu Bir Bakış. Türk Tarih Kongresi, Kongreye Sunulan Bildiriler 8: 135-42.

Alkım, U. Bahadır. 1962. Dördüncü Dönem Tilmen Höyük Kazısı. Türk Arkeoloji Dergisi

12.1: $5-7$

1968. Recent Archaeological Research in Turkey. Anatolian Studies 18: 21-43.

Alkum, U. Bahadır and Handan Alkım. 1966. Excavations at Gedikli, First Preliminary report. Belleten 30: 27-57.

Arbuckle, Benjamin. 2006. The Evolution of Sheep and Goat Pastoralism and Social Complexity in Central Anatolia (Turkey). Ph.D. dissertation. Harvard University. Arsebük, Güven. 1979. Altınova’da (Elazığ), Koyu Yüzlü Açkılı ve Karaz Türü Çanak Çömlek Arasındaki İlişkiler. Türk Tarih Kongresi: Kongreye Sunulan Bildiriler 8: 81-92. - 1983. Tülintepe: Some Aspects of a Prehistoric Village. In Beiträge zur Altertumskunde Kleinasiens, Festschrift für Kurt Bittel, ed. Rainer M. Boehmer and Harald Hauptmann, 51-57. Mainz am Rhein: Philipp von Zabern.

Arzt, Jennifer M. 2001. Excavations at Tell Ziyadeh, Syria: The Northern Ubaid Reconsidered. Ph.D. dissertation. Yale University.

Balossi, Francesca. 2004. New Data for the Definition of the DFBW Horizon and its Internal Developments. Anatolica 30: 109-49.

Balossi Restelli, Francesca. 2008. Post-Ubaid Occupation on the Upper Euphrates: Late Chalcolithic 1-2 at Arslantepe (Malatya, Turkey). In Proceedings of the 4th International Congress of the Archaeology of the Ancient Near East: The Reconstruction of Environment: Natural Resources and Human Interrelations through Time; Art History: Visual Communication, ed. Hartmut von Kühne, Rainer M. Czichon, and Florian Janoscha Kreppner, vol. 2, 21-32. Wiesbaden: Harrassowitz Verlag.

Balossi Restelli, Francesca and Paulo Guarino. 2010. Domestic Behaviour and Cultural Milieu North and South of the Taurus in the Mid IV Millennium BC, as Inferred from the Pottery Production and Use at the Sites of Arslantepe and Zeytinli Bahçe. In Proceedings of the Sixth International Congress on the Archaeology of the Ancient Near East, ed. Paolo Matthiae, 641-652. Roma: Università di Roma "La Sapienza." Barth, Frederic. 1953. Principles of Social Organization in Southern Kurdistan. Oslo: Jørgensen.

1965. Nomads of South Persia, the Baseri Tribe of the Khamseh Confederacy. New York: Humanities Press.

Behm-Blancke, Manfred R., Manfred Hoh, Norbert Karg, Ludwig Masch, Franz Parsche, Karl Ludwig Weiner, Alwo von Wickede, and Gerfried Ziegelmayer. 1984. Hassek Höyük. Vorläufiger Bericht über die Grabungen in den Jahre 1981-1983. Istanbuler Mitteilungen 34: 31-150.

Bernbeck, Reinhard, Sarah Costello, and Necdet Ünal. 2004. Excavations at Yenice Yanı 2002. Kazı Sonuçlart Toplantısı 25: 117-26.

Bernbeck, Reinhard and Susan Pollock. 2003. The Biography of an Early Halaf Village: F1stıklı Höyük 1999-2000. Istanbuler Mitteilungen 53: 9-77.

Bernbeck, Reinhard, Sarah Pollock, and Cheryl Coursey. 1999. The Halaf Settlement at Kazane Höyük: Preliminary Report on the 1996 and 1997 Seasons. Anatolica 25: 109-44. 
Blaylock, Stuart. 1998. Adıyaman Survey 1985-1991. In Ancient Anatolia: Fifty Years' Work by the British Institute of Archaeology at Ankara, ed. Roger Matthews, 101-10. London:

British Institute of Archaeology at Ankara.

Blaylock, Stuart R., David H. French, and Geoffrey D. Summers. 1990. The Adiyaman Survey: An Interim Report. Anatolian Studies 40: 81-135.

Braidwood, Robert J. and Linda S. Braidwood. 1960. Excavations in the Plain of Antioch. Vol. 1. The Earlier Assemblages, Phases A-J. Oriental Institute Publications 61. Chicago: University of Chicago Press.

Breniquet, Catherine. 1987. Nouvelle hypothèse sur la disparition de la culture de Halaf. In Préhistoire de la Mesopotamie, ed. Jean-Louis Huot, 231-41. Paris: Éditions du CNRS.

- 1991. Un site halafien en Turquie méridionale: Tell Turlu. Rapport sur la campagne de fouilles de 1962. Akkadica 71: 1-35.

-1996. La disparition de la culture de Halaf: les origines de la culture d'Obeid dans le nord de la Mésopotamie. Bibliothèque de la délégation archéologique française en Iraq no 9. Paris: Editions Recherche sur les civilizations.

Brown, Gavin H. 1967. Prehistoric Pottery from the Antitaurus. Anatolian Studies 17: 123-64.

Burney, Charles. 1977. From Village to Empire: An Introduction to Near Eastern Archaeology. Oxford: Phaidon Press.

Campbell, Stuart. 1992. Culture, Chronology and Change in the Later Neolithic of North Mesopotamia. Ph.D. dissertation. University of Edinburgh.

2007. Rethinking Halaf Chronologies. Paléorient 33.1: 103-36.
Campbell, Stuart, Elizabeth Carter, Elizabeth Healey, Seona Anderson, Amanda Kennedy, and Sarah Whitcher. 1999. Emerging Complexity on the Kahramanmaraş Plain: The Domuztepe Project 1995-1997. American Journal of Archaeology 103: 395-418.

Campbell, Stuart and Alexandra Fletcher.2010. Questioning the Halaf-Ubaid Transition. The Emergence of Ubaid styles at Tell Kurdu: A Local Perspective. In Beyond the Ubaid: Transformation and Integration in the Late Prehistoric Societies of the Middle East, ed. Robert A. Carter and Graham Philip, 69-83. Chicago: Oriental Institute of the University of Chicago.

Caneva, Isabella. 2004. Of Terraces, Silos and Ramparts (6000-5800). In Mersin-Yumuktepe:

A Reappraisal, ed. Isabella Caneva and Veli Sevin, 45-56. Lecce: Congedo Editore.

Carter, Elizabeth, Hadi Bozkurt, Stuart Campbell, James Snead, and Lynn Swartz. 1997.

Report on the Archaeological Work in Domuztepe and its Environs in 1995. Kazt

Sonuçları Toplantısı 18: 173-88.

Carter, Elizabeth and Stuart Campbell. 2008. The Domuztepe Project. Kazı Sonuçları

Toplantist 29.3: 123-36.

Carter, Elizabeth, Stuart Campbell, and Suellen Gauld. 2003. Elusive Complexity: New

Data from Late Halaf Domuztepe in Southcentral Turkey. Paléorient 29.2: 117-34.

Carter, Elizabeth, Stuart Campbell, and James Snead. 1999. Excavations and Surveys at

Domuztepe 1996. Anatolia Antiqua 7: 1-17.

Casana, Jesse. 2003. From Alalakh to Antioch: Settlement, Land Use, and Environmental Change in the Amuq Valley of Southern Turkey. Ph.D. dissertation. University of Chicago.

Casana, Jesse J. and Tony J. Wilkinson. 2005. Archaeology and Landscapes of the Amuq Region. In The Amuq Valley Regional Projects, Volume 1-Surveys in the Plain of Antioch and Orontes Delta, Turkey, 1995-2002, ed. K. Aslihan Yener, 25-66. Oriental Institute Publications 131. Chicago: Oriental Institute Press. 
Cavallo, Chiara. 1996. The Animal Remains-A Preliminary Account. In Tell Sabi Abyad:

The Late Neolithi. "ettlement, ed. Peter M. M. G. Akkermans, vol. 2, 475-520. İstanbul: Nederlands Historisth-Archaeologisch Instituut.

Copeland, Lorraine. 1979. Chservations on the Prehistory of the Balikh Valley Syria, during the $7^{\text {th }}$ to 4 th Millennia BC. Paléorient 7: 251-75.

Creekmore, Andrew. 2007. The Upper Tigris Archaeological Research Project (UTARP): A Summary and Synthesis of the Late Chalcolithic and Early Bronze Age Remains from the First Three Seasons at Kenan Tepe. Anatolica 33: 75-128.

Cruells, Walter and Olivier Nieuwenhuyse. 2004. The Proto-Halaf Period in Syria: New Sites, New Data. Paléorient 30.1: 47-68.

Davidson, Thomas E. 1977. Regional Variation within the Halaf Ceramic Tradition. Ph.D. dissertation. University of Edinburgh.

Davidson, Thomas E. and Trevor Watkins. 1981. Two Seasons of Excavation at Tell Aqab in the Jezirah, N.E. Syria. Iraq 43:1-18.

de Jesus, Prentiss S. 1980. The Development of Prehistoric Mining and Metallurgy in Anatolia. Oxford: British Archaeological Reports.

Diebold, Benjamin. 2000. Preliminary Report on the Ceramic assemblage at Tell Kurdu. In Tell Kurdu Excavations 1999, ed. K. Aslihan Yener, Christopher Edens, Jesse Casana, Benjamin Diebold, Heidi Ekstom, Michelle Loyet, and Rana Özbal. Anatolica 26: 58-65. Dönmez, Ahmet and William Charles Brice. 1949. The Distribution of Some Varieties of Early Pottery in Southeast Turkey. Iraq 11: 44-58.

du Plat Taylor, Joan, Marjory Veronica Seton Williams, and John Waechter. 1950. The Excavations at Sakçe Gözü. Iraq 12: 53-138.

Edens, Christopher. 1996. Hacinebi Chipped Stone-1995. In Hactnebi, Turkey: Preliminary Report on the 1995 Excavations. Anatolica 22: 100-104.

- 1997. Chipped Stone. In Excavations at Hacmebi Turkey-1996: Preliminary Report. Anatolica 23: 124-27.

1999. The Chipped Stone Industry at Hacinebi: Technological Styles and Social Identity. Paléorient 25.1: 23-34.

Edens, Christopher and K. Aslihan Yener. 200o. Excavations at Tell Kurdu, 1996 and 1998. American Journal of Archaeology 104: 198-215.

Ehmann, Dieter. 1975. Bahtiyaren-Persische Bergnomaden im Wandel der Zeit B 15.

Wiesbaden: Beihefte zum Tübinger Atlas des Vorderen Orients.

Erinç, Sirrı. 1980. Kültürel Çevrebilim Açısından Güneydoğu Anadolu. In İstanbul ve Chicago Universiteleri Karma Projesi Güneydoğu Anadolu Tarihöncesi Araştırmalar, ed. Halet Çambel and Robert Braidwood, 65-82. İstanbul: İstanbul Edebiyat Fakültesi Yayinları.

Esin, Ufuk. 1976. Tepecik Excavations, 1972. In Keban Project 1972 Activities, 97-117. Ankara: Middle East Technical University Press.

- 1983. Zur Datierung der vorgeschichtlichen Schichten von Değirmentepe bei Malatya in der östlichen Türkei. In Beiträge zur Altertumskunde Kleinasiens. Festschrift Kurt Bittel, ed. Rainer M. Boehmer and Harald Hauptmann, 175-9o. Mainz: Philipp von Zabern.

- 1985. Some Small Finds from the Chalcolithic Occuption at Değirmentepe (Malatya) in Eastern Turkey. In Studi di paletnologia in onore di Salvatore M. Puglisi, ed. Mario Liverani, Alba Palmieri, and Renato Peroni, 253-64. Roma: Università di Roma "La Sapienza."

-1989. An Early Trading Center in Eastern Anatolia. In Anatolia and the Ancient Near East, Studies in Honor of Tahsin Özgüç, ed. Kutlu Emre, Barthel 
Hrouda, Machteld Mellink, and Nimet Özgüç, 135-41. Ankara: iürk Tarih Kurumu Basımevi.

1993. The Relief Decorations on the Prehistoric Pottery of "alintepe in Eastern Anatolia. In Between the Rivers and over the Mountains: A.chaeologica Anatolica et Mesopotamica Alba Palmieri Dedicata, ed. Marcella Frangipane, Harald Hauptmann, Mario Liverani, Paolo Matthiae, and Machteld Mellink, 105-19. Roma: Università di Roma "La Sapienza."

-1994. The Functional Evidence of Seals and Sealings of Değirmentepe. In Archives before Writing, ed. Piera Ferioli, Enrica Fiandra, Gian Giacomo Fissore, and Marcella Frangipane, 59-81. Roma: Università di Roma "La Sapienza."

1996. Doğu Anadolu'da Bulunan Obeyd Tipi Çanak Çömlek ve Değirmentepe (Malatya) Kazısı. In Türk Tarih Kongresi 9. Kongreye Sunulan Bildiriler, vol. 1, 81-92. Ankara: Türk Tarih Kurumu.

Esin, Ufuk and Güven Arsebük. 1974. 'lülintepe Kazıs1 1971. Turk Arkeoloji Dergisi 20.2: 63-7ð. 1982. Tülintepe Kazısı. Keban Projesi 1974-1975 Calışmaları, 119-34. Ankara: Middle

East Technical University Series.

Esin, Ufuk and Savaş Harmankaya. 1986. 1984 Değirmentepe (Malatya) Kurtarma Kazısı. Kazı Sonuçları Toplantısı 7: 53-85.

—. 1987. 1985 Değirmentepe (Malatya-İmamlı Köyü) Kurtarma Kazısı. Kazı Sonuçlart Toplantısi 8: 95-137.

1988. Değirmentepe (Malatya) Kurtarma Kazısı 1986. Kazı Sonuçları Toplantısı 9: 79-125.

Evin, Jacques. 1995. Possibilité et nécessité de la calibration des datations C-14 de

l'archéologie du Proche-Orient. Paléorient 21: 5-16.

Ferioli, Piera and Enrica Fiandra. 1983. Clay Sealings from Arslantepe VI: Administration and Bureaucracy. Origini 12.2: 455-509.

Fletcher, Alexandra. 2007. The Prehistoric Ceramic Assemblage from Horum Höyük. Anatolian Studies 57: 191-202.

Foster, Catherine P. 2009. Household Archaeology and the Uruk Phenomenon: A Case Study from Kenan Tepe, Turkey. Ph.D. dissertation. University of California.

Frangipane, Marcella. 1993. Local Components in the Development of Centralized Societies in Syro-Anatolian Regions. In Between the Rivers and over the Mountains: Archaeologica Anatolica et Mesopotamica Alba Palmieri Dedicata, ed. Marcella Frangipane, Harald Hauptmann, Mario Liverani, Paolo Matthiae, and Machteld Mellink, 133-61. Roma: Università di Roma "La Sapienza."

- 1994. The Record Function of Clay Sealings in Early Administrative Systems as Seen from Arslantepe-Malatya. In Archives before Writing. Piera Ferioli, Enrica Fiandra, Gian Giacomo Fissore, and Marcella Frangipane, 125-37. Roma: Università di Roma "La Sapienza."

-1997a. Arslantepe-Malatya: External Factors and Local Components in the Development of Early State Society. In Emergence and Change in Early Urban Societies, ed. Linda Manzanilla, 43-58. New York: Plenum Press.

-1997b. A Fourth Millennium Temple/Palace Complex at Arslantepe-Malatya. North South Relations and the Formation of Early State Societies in the Northern Regions of Southern Mesopotamia. Paléorient 23: 45-73.

-2007. Different Types of Egalitarian Societies and the Development of Inequality in early Mesopotamia. World Archaeology 39.2: 151-76.

Frangipane, Marcella and Francesca Balossi. 2004. The 2002 Exploration Campaign at Arslantepe-Malatya. Kazı Sonuçları Toplantısı 25.1: 397-404. 
French, David. 1985. Mersin and Tell esh-Sheikh. In Studi di paletnologia in onore di

Salvatore M. Puglisi, ed. Mario Liverani, Alba Palmieri, and Renato Peroni, 265-71.

Roma: Università di Roma "La Sapienza."

French, David and Geoffrey Summers. 1988. Sakçagözü Material in the Gaziantep

Museum. Anatolian Studies 38: 71-84.

Fuensanta, Jesus Gil, Eyüp Bucak, Eduardo Crivelli, Petr Charvat, and Rafael Moya. 2006.

The Research of the Tilbes Project, 2004. Kazı Sonuçları Toplantısı 27.2: 445-52.

Fuensanta, Jesus Gil, Eyüp Bucak, Eduardo Crivelli, Hasan Karabulut, Herbert Sauren, Petr

Charvat, and Rafael Moya. 2007. The Tilbes Project Research in 2005: Surtepe Höyük

Excavations. Kazı Sonuçlart Toplantısı 28.2: 457-70.

Garstang, John. 1943. The Discoveries at Mersin and Their Significance. American Journal of Archaeology 47.1: 1-14.

-1953. Prehistoric Mersin. Oxford: Clarendon Press.

Garstang, John and Hetty Goldman. 1947. A Conspectus of Early Cilician Pottery. American Journal of Archaeology 51.4: 370-88.

Gibson, McGuire, Arm Al-Azm, Clemens Reichel, Salam Quntar, Judith Franke, Lamya

Khalidi, Carrie Hritz, Mark Altaweel, Colleen Coyle, and Carlo Colantoni. 2002.

Hamoukar: A Summary of Three Seasons of Excavation. Akkadica 123.1: 11-34.

Goldman, Hetty. 1956. Excavations at Gözlï Kule, Tarsus: From the Neolithic through the

Bronze Age. Princeton, N.J.: Princeton University Press.

Gülçur, Sevil. 200o. Norşuntepe: Die Chalkolithische Keramik (Elazığ/Ostanatolien). In

Chronologies des pays du Caucase et de L'Euphrate aux IVe-IIIe Millénaires, ed.

Catherine Marro and Harald Hauptmann, 375-418. Institut Français d'Etudes

Anatoliennes d'Istanbul, Varia Anatolica XI. Paris: De Boccard.

Gürdil, Bekir. 2002. A Late Halaf Site in the Kahramanmaras Valley. Anatolica 28: 137-58.

-2005. Architecture and Social Complexity in the Late Ubaid Period: A Study of the

Built Environment of Değirmentepe in East Anatolia. Ph.D. dissertation. University of

California, Los Angeles.

- 2010. Exploring Social Organizational Aspects of the Ubaid Communities: A Case

Study of Değirmentepe in Eastern Turkey. In Beyond the Ubaid: Transformation and

Integration in the Late Prehistoric Societies of the Middle East, ed. Robert A. Carter and

Graham Philip, 361-375. Chicago: Oriental Institute of the University of Chicago.

Hammade, Hamido and Yayoi Koike. 1992. Syrian Archaeological Expedition in the

Tishreen Dam Basin: Excavations at Tell al Abr 1990 and 1991. Damascener Mitteilungen

6: $107-75$.

Hammade, Hamido and Yayoi Yamazaki. 1995. A Preliminary Report on the Excavation at Tell al-'Abr on the Upper Euphrates, 1992. Akkadica 93: 4-10.

- 2006. Tell al-'Abr (Syria). Ubaid and Uruk Periods. Publications de la Mission archéologique de l'Université de Liège en Syrie. Leuven: Peeters.

Hauptmann, Harald. 1976. Die Grabungen auf dem Norşun Tepe. Keban Activities. Ankara: Middle East Technical University Series.

-1982. Die Grabungen auf dem Norşun Tepe. Keban Activities. Ankara: Middle East Technical University.

Helwing, Barbara. 1999. Cultural Interaction at Hassek Höyük, Turkey: New Evidence from Pottery analysis. Paléorient 25:95-101.

- 2002. Hassek Höyük II: Die spätchalkolithische Keramik. Istanbuler Forschungen Band 45. Tübingen: Ernst Wasmuth.

$\longrightarrow$ 2003. Feasts as a Social Dynamic in Prehistoric Western Asia-Three Case Studies from Syria and Anatolia. Paléorient 29.2: 63-85. 
Hood, Sinclair. 1951. Excavations at Tabara el Akrad, 1948-49. Anatolian Studies 1: 113-47.

Irons, William. 1972. Variation in Economic Organization: A Comparison of the Pastoral Yomut and the Basseri. In Perspectives on Nomadism, ed. William Irons and Neville Dyson-Hudson, 88-104. Leiden: Brill.

-1974. Nomadism as a Political Adaptation: The Case of the Yomut Turkmen. American Ethnologist 1: 635-58.

1975. The Yomut Turkmen: A Study of Social Organization among a Central Asian Turkic-Speaking Population. Anthropological Papers 58. Ann Arbor, Mich.: Museum of Anthropology Publications.

Kansa, Sarah Whitcher and Stuart Campbell. 2002. Feasting with the Dead? A Ritual Bone Deposit at Domuztepe, Southeastern Turkey (c. 5550 cal BC). In Behaviour Behind Bones: The Zooarchaeology of Ritual, Religion, Status and Identity, ed. Sharyn Jones O'Day, Wim Van Neer, and Anton Ervynck, 2-13. International Council of Archaeozoology. Durham: Oxbow.

Kansa, Sarah Whitcher, Suellen C. Gauld, Stuart Campbell, and Elizabeth Carter. 2009. Whose Bones Are Those? Preliminary Comparative Analysis of Fragmented Human and Animal Bones in the "Death Pit" at Domuztepe, a Late Neolithic Settlement in Southeastern Turkey. Anthropozoologia 44.1: 159-72.

Karaca, Özgen. 1985. Pirot Höyük 1983 Kazıları. Kazı Sonuçları Toplantısı 6.1: 37-48.

Keith, Kathryn. 1998. Spindle Whorls, Gender, and Ethnicity at Late Chalcolithic Hacinebi Tepe. Journal of Field Archaeology 25.4: 497-515.

Kennedy, Jason R. 2008. Terminal Ubaid Ceramics at Yenice Yani: Implications for Terminal Ubaid Organization of Labor and Commensality. M.A. thesis. State University of New York, Binghamton.

Korfmann, Manfred. 1982. Tilkitepe: Die ersten Ansätze prähistorischer Forschung in der östlichen Türkei. Tübingen: Ernst Wasmuth.

Kozbe, Gülriz. 2006. Şırnak İli, Cizre-Silopi Ovası 2004 Yılı Yüzey Araştırması. Araştırma Sonuçları Toplantısı 23.1: 293-308.

- 2007. Şırnak İli Cizre-Silopi Ovası Yüzey Araştırması, 2005. Araştırma Sonuçları Toplantısi 24.1: 307-26.

—. 2008. Şırnak İli Yüzey Araştırmaları, 2006. Araştırma Sonuçları Toplantısı 25.1: 175-86.

Leenders, Roger. 1989. The Red Wash Ware Ceramic Assemblage in Syria: A Review. In To the Euphrates and Beyond: Archaeological Studies in Honor of Maurits van Loon, ed. Odette M.C. Haex, Hans H. Curvers, and Peter M. M. G. Akkermans, 89-102. Rotterdam: Balkema.

Lloyd, Seton and Fuad Safar. 1943. Tell Uqair: Excavations by the Iraq Government Directorate of Antiquities in 1940-41. Journal of Near Eastern Studies 2: 131-58.

Lupton, Alan. 1996. Stability and Change: Socio-Political Development in North Mesopotamia and South-East Anatolia 400o-2700 BC. BAR International Series 627. Oxford: Tempus Reparatum.

Mallowan, Max E. L. 1946. Excavations in the Balikh Valley (1938). Iraq 8: 111-56.

Mallowan, Max E. L. and John C. Rose. 1935. Excavations at Tell Arpachiyah, 1933. Iraq 2: 1-178.

Marfoe, Leon and Michael L. Ingraham. 1990. Area A. In Town and Country in Southeastern Anatolia. Vol. II. The Stratigraphic Sequence at Kurban Höyük, ed. Guillermo Algaze, 23-63. Oriental Institute Publications 110. Chicago: Oriental Institute Press.

Matthews, Roger D. 2003. The Archaeology of Mesopotamia: Theories and Approaches. New York: Routledge. 
McCarty, Sue Ann. 2009. Telling the Future or Hoarding the Past?: A Halaf Cattle Astragalus Cache from Kazane Höyük, Southeastern Turkey. Poster presented at the Interpreting the Late Neolithic Conference, organized by P. Akkermans, R. Bernbeck, and O. Nieuwenhuyse. Leiden, 26-28 March 2009.

Mellink, Machteld. 1989. Archaeology in Asia Minor. American Journal of Archaeology 93: 105-33.

-1991. Archaeology in Anatolia. American Journal of Archaeology 95: 123-53.

Miyake, Yutaka. 2007. Salat Cami Yanı: Dicle Havzası'nda Çanak Çömlekli Neolitik Döneme Ait Yeni Bir Yerleşme. In Türkiye’de Neolitik Dönem ed. Mehmet Özdoğan and Nezih Başgelen. İstanbul: Arkeoloji ve Sanat Yayınları.

Nieuwenhuyse, Olivier. 2007. Plain and Painted Pottery: The Rise of Late Neolithic Ceramic Styles on the Syrian and Northern Mesopotamian Plains. Turnhout: Brepols.

Nieuwenhuyse, Olivier, Peter M. M. G. Akkermans and Johannes van der Plicht. 2010. Not So Coarse, Nor Always Plain - The Earliest Pottery of Syria. Antiquity 84: 71-85.

Nissen, Hans. 2000. Mesopotamian Hierarchy in Action in Ancient Uruk. In Hierarchies in Action. Cui Bono?, ed. Michael Diehl, 210-17. Carbondale: Center for Archaeological Investigations, Southern Illinois University.

Oates, Joan. 1993. Trade and Power in the Fifth and Fourth Millennia BC: New Evidence from Northern Mesopotamia. World Archaeology 24.3: 403-22.

Oates, Joan and David Oates. 1997. An Open Gate: Cities of the Fourth Millennium BC (Tell Brak 1997). Cambridge Archaeological Journal 7: 287-97.

- 2004. The Role of Exchange Relations in the Origins of Mesopotamian Civilization. In Explaining Social Change: Studies in Honour of Colin Renfrew, ed. John Cherry, Chris Scarre, and Stephen Shennan, 177-92. Cambridge: McDonald Institute Monographs.

Oates, Joan, Augusta McMahon, Philip Karsgaard, Salam Al Quntar, and Jason Ur. 2007. Early Mesopotamian Urbanism: A New View from the North. Antiquity 81: 585-60o.

Ozan, Ali. 2009. Siirt-Botan vadisinde Ubaid Dönemi. In Altan Çilingiroğlu'na Armağan: Yukarı Denizin Kıyısında Urartu Krallıgı'na Adanmış Bir Hayat (Studies in Honour of Altan Çilingiroğlu: A Life Dedicated to Urartu on the Shores of the Upper Sea), ed. Haluk Sağlamtimur, Eşref Abay, Zafer Derin, Aylin Ü. Erdem, Atilla Batmaz, Fulya Dedeoğlu, Mücella Erdalkıran, Mahmut B. Baştürk, and Erim Konakçı, 407-25. İstanbul: Arkeoloji ve Sanat Yayinları.

- Forthcoming. Halaf döneminde Botan, Garzan ve Batman vadilerinin Siirt-Türbe Höyük kazıları ısı̆ğında değerlendirilmesi. Paper presented at the 1. Uluslararası Batman ve Çevresi Tarih ve Kültür Sempozyumu, Batman.

Özbal, Hadi. 1996. Chemical Analysis of a Copper Chisel from Hacinebi Tepe. Anatolica 22: 109-10.

_. 1997. Early Metal Technology at Hacinebi Tepe. In "Excavations at Hacinebi Turkey-1996: Preliminary Report." Anatolica 23: 139-43.

Özbal, Hadi, Mieke Adriaens, and Brian Earl. 1999. Hacinebi Metal Production and Exchange. Paléorient 25.1: 57-66.

Özbal, Rana. 2006. Households, Daily Practice and Cultural Appropriation at Sixth Millennium Tell Kurdu. Ph.D. dissertation. Northwestern University.

-2010. The Emergence of Ubaid Styles at Tell Kurdu: A Local Perspective. In Beyond the Ubaid: Transformation and Integration in the Late Prehistoric Societies of the Middle East, ed. Robert A. Carter and Graham Philip, 293-310. Chicago: Oriental Institute of the University of Chicago. 
Özbal, Rana, Fokke Gerritsen, Benjamin Diebold, Elizabeth Healey, Nihal Aydın, Michelle Loyet, Frank Nardulli, David Reese, Heidi Ekstrom, Sabrina Sholts, Nitzan Mekel-Bobrov, and Bruce Lahn. 2004. Tell Kurdu Excavations 2001. Anatolica 30: 37-108.

Özbal, Rana, Fokke Gerritsen, and K. Aslıhan Yener. 2003. 2001 Tell Kurdu Kazıları. Kazı Sonuçları Toplantısi 24.1: 501-12.

Özbaşaran, Mihriban. 1992. Doğu ve Güneydoğu Anadolu Kalkolitik Mimarisinde Tülintepe Yerleşmesinin Yeri. Ph.D. dissertation. İstanbul Üniversitesi.

Özdoğan, Mehmet. 1977. Lower Euphrates Basin: 1977 Survey. Middle East Technical University. Lower Euphrates Project Publications, series 1, no. 2. Ankara: Orta Doğu Teknik Üniversitesi.

Özdoğan, Mehmet and Aslı Özdoğan. 1993. Pre-Halafian Pottery of Southeastern Anatolia with Special Reference to the Çayönü Sequence. In Between the Rivers and over the Mountains: Archaeologica Anatolica et Mesopotamica Alba Palmieri Dedicata, ed. Marcella Frangipane, Harald Hauptmann, Mario Liverani, Paolo Matthiae, and Machteld Mellink, 87-103. Roma: Università di Roma "La Sapienza."

Özgen, Engin, Barbara Helwing, and Atilla Engin. 2002. The Oylum Regional Project: Archaeological Prospection 2000. Araştırma Sonuçları Toplantısı 19.2: 217-28.

Özgen, Engin, Barbara Helwing, Atilla Engin, Olivier Nieuwenhuyse, and Richard Spoor. 1999. Oylum Höyük 1997-1998. Die spätchalkolithische Siedlung auf der Westterrasse. Anatolia Antiqua 7: 19-67.

Özgen, Engin, Barbara Helwing, Lothar Herling, and Atilla Engin. 2003. The Oylum Höyük Regional Project: Results of the 2001 Prospection Season. Araştırma Sonuçları Toplantıst 20.2: 151-58.

Özgüç, Nimet. 1992. The Uruk Culture at Samsat. In Von Uruk nach Tuttul. Eine Festschrift für Eva Strommenger: Studien und Aufsätze von Kollegen und Freunden, ed. Barthel Hrouda, Stephan Kroll, and Peter Z. Spanos, 151-65. München: Profil.

Özgüç, Tahsin. 1956. Fraktin Kabartması Yanındaki Prehistorik Ev. Anadolu 1.1: 59-64. Öztan, Aliye. 2002. Köşk Höyük: Anadolu Arkeolojisine Yeni Katkular. Tüba-Ar 5: 55-69.

Palmieri, Alberto M., Kemal Sertok, and Evgenij Chernykh. 1993. From Arslantepe Metalwork to Arsenical Copper Technology in Eastern Anatolia. In Between the Rivers and over the Mountains: Archaeologica Anatolica et Mesopotamica Alba Palmieri Dedicata, ed. Marcella Frangipane, Harald Hauptmann, Mario Liverani, Paolo Matthiae, and Machteld Mellink, 563-99. Roma: Università di Roma "La Sapienza."

Parker, Bradley and Andrew Creekmore. 2002. The Upper Tigris Archaeological Research Project: A Final Report from the 1999 Field Season. Anatolian Studies 52: 19-74.

Parker, Bradley, Catherine P. Foster, Jennifer Henecke, Marie Hopwood, David Hopwood, Andrew Creekmore, Arzu Demirergi, and Melissa Eppihimer. 2008. Preliminary Report from the 2005-2006 Field Seasons at Kenan Tepe. Anatolica 34: $103-76$.

Parker, Bradley J., Catherine P. Foster, Kathleen Nicoll, Jason R. Kennedy, Philip Graham, Alexia Smith, David E. Hopwood, Marie Hopwood, Kristin Butler, Elizabeth Healey, M. Barış Uzel, and Reilly Jensen. 2009. The Upper Tigris Archaeological Research Project (UTARP): A Preliminary Report from the 2007 and 2008 Field Seasons at Kenan Tepe. Anatolica 35.1: 85-152.

Pearce, Julie. 200o. The Late Chalcolithic Sequence at Hacınebi Tepe, Turkey. In Chronologies des Pays du Caucause et de l'Euphrate aux IVe-IIIe Millénaires, ed. Catherine Marro and Harald Hauptmann, 115-44. Institut Français d'Etudes Anatoliennes d'Istanbul, Varia Anatolica XI. Paris: De Boccard. 
2008. Hacinebi Tepe and the Uruk Expansion: A Ceramic Perspective on Culture

Contact. Ph.D. dissertation. University of Pennsylvania.

perkins, Ann L. 1949. The Comparative Archaeology of Early Mesopotamia. Chicago:

University of Chicago Press.

pittman, Holly. 1996. Preliminary Report on Glyptic Art: Hacinebi 1993. In Uruk Colonies and Mesopotamian Communities: An Interim Report on the 1992-1993 Excavations at Hacmebi, Turkey. American Journal of Archaeology 100.2: 230-33.

-1999. Administrative Evidence from Hacinebi Tepe: An Essay on the Local and the Colonial. Paléorient 25.1: 43-50.

- 2001. Mesopotamian Intra-Regional Relations Reflected through Glyptic Evidence in the Late Chalcolithic. In Uruk Mesopotamia and its Neighbors: Cross-Cultural Interactions in the Era of State Formation, ed. Mitchell S. Rothman, 403-44. Santa Fe, N.M.: School of American Research Press.

pollock, Susan. 1992. Bureaucrats and Managers, Peasants and Pastoralists, Imperialists and Traders: Research on the Uruk and Jemdet Nasr Periods in Mesopotamia. Journal of World Prehistory 6: 297-336.

- Forthcoming. Subjects and Objects: Defining a Halaf Tradition. In Interpreting the Late Neolithic of Upper Mesopotamia, ed. Anna Russell, Olivier P. Nieuwenhuyse, Peter M. M. G. Akkermans, and Reinhard Bernbeck. Turnhout: Brepols.

Redman, Charles L. 1978. The Rise of Civilization: From Early Farmers to Urban Society in the Ancient Near East. San Francisco: Freeman.

Reichel, Clemens. 2002. Administrative Complexity in Syria during the Fourth Millennium BC: The Seals and Sealings from Tell Hamoukar. Akkadica 123: 35-56.

Reilly, Edward Bowen. 1940. Test Excavations at Tilkitepe (1937). Türk Tarih, Arkeologya ve Etnografya Dergisi 4: 145-65.

Rosenberg, Michael and Hakan Togul, 1991. The Batman River Archaeological Site Survey, 1990. Anatolica 17: 241-54.

Rothman, Mitchell S. 2001a. The Local and the Regional: An Introduction. In Uruk Mesopotamia and its Neighbors: Cross-Cultural Interactions in the Era of State Formation, ed. Mitchell S. Rothman, 3-26. Santa Fe, N.M.: School of American Research Press. - 2001b. The Tigris Piedmont, Eastern Jazira, and Highland Western Iran in the Fourth Millennium BC. In Uruk Mesopotamia and its Neighbors: Cross-Cultural Interactions in the Era of State Formation, ed. Mitchell S. Rothman, 349-403. Santa Fe, N.M.: School of American Research Press.

Rothman, Mitchell and Gülriz Kozbe. 1997. Muş in the Early Bronze Age. Anatolian Studies 47: $105-26$.

Russell, Henry F. 1980. Pre-Classical Pottery of Eastern Anatolia: Based on a Survey by Charles Burney of Sites along the Euphrates and around Lake Van. BAR International Series 85. Oxford: British Archaeological Reports.

Sagona, Antonio and Paul Zimansky. 2009. Ancient Turkey. London: Routledge.

Sağlamtimur, Haluk. 2009. Ilısuya Yeni Kurban: Botan'da 9 Bin Yll. Atlas 119 (Subat): 36-37. Sağlamtimur, Haluk and Ali Ozan. 2007. Siirt-Türbe Höyük Kazısı-Ön Rapor (Siirt-Türbe Höyük Excavation-Preliminary Report). Arkeoloji Dergisi (Ege Üniversitesi Edebiyat Fakültesi Yaytnlari) 10.2: 1-32.

Schachner, Andreas. 2003. 2000-01 Y1lı Giricano Kazıları. Kazt Sonuclart Toplantıst 24.2: $447-60$.

-2004. Vorbericht über die Ausgrabungen in Giricano, 2001. In TAÇDAM: Activities in 2001, ed. Numan Tuna, Jean Özturk, and Jale Velibeyoğlu, 505-46. Ankara: Middle East Technical University Press. 
Schachner, Andreas, Michael Roaf, Karen Radner, and Rainer Pasternak, 2002. Vorläufiger Bericht über die Ausgrabungen in Giricano. In TAÇDAM: Activities in 2ooo, ed.

Numan Tuna and Jale Velibeyoğlu, 587-630. Ankara: Middle East Technical University Press.

Seeden, H. and M. Kaddour. 1983. Space, Structures and Land in Shams ed-Din Tannira on the Euphrates: An Ethnoarchaeological Perspective. In Land Tenure and Social

Transformation in the Near East, ed. Tarif al-Khalidi, 495-526. Beirut: American University of Beirut Press.

Steadman, Sharon R. 1996. Isolation or Interaction: Prehistoric Cilicia and the Fourth Millennium Uruk Expansion. Journal of Mediterranean Archaeology 9.2: 131-65.

-2000. Spatial Patterning and Social Complexity on Prehistoric Anatolian Tell Sites, Models for Mounds. Journal of Anthropological Archaeology 19: 164-99.

Stein, Gil. 1999. Rethinking World-Systems: Diasporas, Colonies, and Interaction in Uruk Mesopotamia. Tucson: University of Arizona Press.

2001. Indigenous Social Complexity at Hacinebi (Turkey) and the Organization of Uruk Colonial Contact. In Uruk Mesopotamia and its Neighbors: Cross-Cultural

Interactions in the Era of State Formation, ed. Mitchell S. Rothman, 265-306. Santa Fe, N.M.: School of American Research Press.

- 2002. From Passive Periphery to Active Agents: Emerging Perspectives in the Archaeology of Interregional Interaction. American Anthropologist 104: 903-16.

Stein, Gil J., Reinhard Bernbeck, Cheryl Coursey, Augusta McMahon, Naomi F. Miller, Adnan Misir, Jeffrey Nicola, Holly Pittman, Susan Pollock, and Henry Wright. 1996. Uruk Colonies and Anatolian Communities: An Interim Report on the 1992-1993 Excavations at Hacinebi, Turkey. American Journal of Archaeology 100.2: 205-60.

Stein, Gil J., Christopher Edens, Julie P. Edens, Kenneth Boden, Nicola Laneri, Hadi Özbal, Brian Earl, Mieke Adriaens, and Holly Pittman. 1998. Southeastern Anatolia before the Uruk Expansion: Preliminary Report on the 1997 Excavations at Hacinebi, Turkey. Anatolica 24: 143-93.

Stein, Gil and Jeffrey Nicola. 1996. Late Chalcolithic Faunal Remains from Hacinebi. In Uruk Colonies and Mesopotamian Communities: An Interim Report on the 1992-3 Excavations at Hacmebi, Turkey. American Journal of Archaeology 100: 205-60.

Stein, Gil and Rana Özbal. 2007. A Tale of Two Oikumenai: Variation in the Expansionary Dynamics of Ubaid and Uruk Mesopotamia. In Settlement and Society: Ecology, Urbanism, Trade and Technology in Mesopotamia and Beyond (Robert McC. Adams Festschrift), ed. Elizabeth C. Stone, 356-70. Los Angeles: Cotsen Institute of Archaeology Press.

Summers, Geoffrey D. and David H. French. 1992. 1990 Adıyaman Yüzey Araştırması. Araştırma Sonuçları Toplantısı 9.1: 505-22.

Sürenhagen, Dietrich. 1986. The Dry-Farming Belt: The Uruk Period and Subsequent Developments. In The Origins of Cities in Dry-Farming Syria and Mesopotamia in the Third Millennium B.C., ed. Harvey Weiss, 7-43. Guilford: Four Quarters.

Şenyurt, S. Y. 2002. 2000 Excavations at Aşağ Salat. In TAÇDAM: Activities in 2000, ed. Numan Tuna, Jean Öztürk, and Jale Velibeyoğlu, pp. 688-722. Ankara: Middle East Technical University Press.

Tapper, Richard. 1979. The Organization of Nomadic Communities in Pastoral Societies of the Middle East. In Pastoral Production and Society, 43-65. Cambridge: Cambridge University Press.

Tekin, Halil. 2003. Hakemi Use 2001 Kazısı. Kazı Sonuçları Toplantısı 24: 59-70. 
2007. Hakemi Use: Güneydoğu Anadolu'da Son Neolitik Döneme ait yeni bir merkez. In Türkiye’de Neolitik Dönem, ed. Mehmet Özdoğan and Nezih Başgelen, 47-56. İstanbul: Arkeoloji ve Sanat Yayınlar1.

Thissen, Laurens. 1985. The Late Chalcolithic and Early Bronze Age Pottery from Hayaz Höyük. Anatolica 12: 75-130.

Tobler, Artur. 1950. Excavations at Tepe Gawra, vol. 2. Philadephia: University of Pennsylvania Press.

Trufelli, Franca. 1994. Standardisation, Mass Production and Potters' Marks in the Late Chalcolithic Pottery of Arslantepe (Malatya). Origini 18: 248-89.

1997. Ceramic Correlations and Cultural Relations in IVth Millennium Eastern Anatolia and Syro-Mesopotamia. Studi Micenei ed. Egeo-Anatolici 39.1: 5.

Uerpmann, Hans-Peter, 1982. Faunal Remains from Shams ed-Din Tannira, a Halafian Site in Northern Syria. Berytus 30: 3-52.

Ur, Jason. 2002. Settlement and Landscape in Northern Mesopotamia: 'The 'l'ell Hamoukar Survey 2000-2001. Akkadica 123: 57-88.

Ur, Jason, Philip Karsgaard, and Joan Oates. 2007. Early Urban Development in the Near East. Science 317: 1188.

van Loon, Maurits. 1978. Architecture and Stratigraphy. In Korucutepe. Final Report on the Excavations of the Universities of Chicago, California (Los Angeles) and Amsterdam in the Keban Reservoir, Eastern Anatolia 1968-1970, ed. Maurits van Loon, 3-11. Amsterdam: North-Holland.

Velibeyoğlu, Jale A., Andreas Schachner, and Şenay Schachner. 2002. Botan Vadisi ve Çattepe (Tilli) Yüzey Araştırmalarının Illk Sonuçları. In Salvage Project of the Archaeological Heritage of the Ilisu and Carchemish Dam Reservoirs, Activities in 20oo, ed. Numan Tuna and Jale Velibeyoğlu, 783-835. Ankara: Middle East Technical University.

von Wickede, Alwo and Suzanne Herbordt. 1988. Çavi Tarlası. Bericht über die Ausgrabungskampagnen 1983-1984. Istanbuler Mitteilungen 38: 5-36.

Waechter, John, Sabahat Gögüs, and Marjory Veronica Seton Williams. 1951. The Sakçe Gözü Cave Site 1949. Belleten 15: 193-201.

Watson, Patty Jo. 1983. The Halafian Culture: A Review and Synthesis. In The Hilly Flanks and Beyond: Essays on the Prehistory of Southwestern Asia Presented to Robert J. Braidwood, ed. T. Cuyler Young, Philip E. L. Smith, and Peder Mortensen, 231-49. Studies in Ancient Oriental Civilization 36. Chicago: Oriental Institute.

Watson, Patty Jo and Stephen LeBlanc. 1990. Girikihaciyan: A Halafian Site in Southeastern Turkey. Institute of Archaeology Monographs 33. Los Angeles: University of California Institute of Archaeology.

Whallon, Robert. 1979. An Archaeological Survey of the Keban Reservoir Area of EastCentral Turkey. Ann Arbor: University of Michigan, Museum of Anthropology.

Woolley, C. Leonard. 1934. The Prehistoric Pottery from Carchemish. Iraq 1: 146-62.

-1959. A Forgotten Kingdom: Being a Record of the Results Obtained from the Excavations of Two Mounds, Atchana and Al Mina in the Turkish Hatay, rev. ed. London: Parrish.

Wright, Henry. 2001. Cultural Action in the Uruk World. In Uruk Mesopotamia and its Neighbors: Cross-Cultural Interactions in the Era of State Formation, ed. Mitchell S. Rothman, 123-49. Santa Fe, N.M.: School of American Research Press.

Wright, Henry and Gregory Johnson. 1975. Population, Exchange, and Early State Formation in Southwestern Iran. American Anthropologist 77.2: 267-89.

Wright, Henry and Eric Rupley. 2001. Calibrated Radiocarbon Age Determinations of Uruk-Related Assemblages. In Uruk Mesopotamia and its Neighbors: Cross-Cultural 
Interactions in the Era of State Formation, ed. Mitchell S. Rothman, 85-122. Santa Fe, N.M.: School of American Research Press.

Wright, Henry T. and Robert Whallon. 1998. Investigations at Fatmalı Kalecik: A Chalcolithic Hamlet in the Upper Euphrates Valley. In Light at the Top of the Black Hill: Studies Presented to Halet Çambel, ed. Güven M. Arsebük, Machteld J. Mellink, and Wulf Schirmer, 775-810. İstanbul: Ege Yayınlar1.

Yakar, Jak and Ayşe Gürsan-Salzmann. 1978. The Provinces of Malatya and Sivas. Expedition 20: 59-62.

Yardimc1, Nurettin. 1993. Excavations, Surveys and Restoration Works at Harran. In Between the Rivers and over the Mountains: Archaeologica Anatolica et Mesopotamica Alba Palmieri Dedicata, ed. Marcella Frangipane, Harald Hauptmann, Mario Liverani, Paolo Matthiae, and Machteld Mellink, 437-52. Roma: Università di Roma "La Sapienza."

- 2001. 1999 Yılı Harran Yüzey Araştırması Çalışmaları. Araştırma Sonuçları Toplantist 18.2: 45-56.

Yener, K. Aslihan. 200o. The Domestication of Metals: The Rise of Complex Metal Industries in Anatolia. Leiden: Brill.

Yener, K. Aslıhan, Christopher Edens, Jesse Casana, Benjamin Diebold, Heidi Ekstrom, Michelle Loyet, and Rana Özbal. 2000a. Tell Kurdu Excavations 1999. Anatolica 26: 32-11\%.

Yener, K. Aslıhan, Christopher Edens, Timothy P. Harrison, Jan Verstraete, and Tony J. Wilkinson. 200ob. The Amuq Valley Regional Project, 1995-1998. American Journal of Archaeology 104: 163-220.

Young, T. Cuyler. 1986. Godin Tepe Period VI/V and Central Western Iran at the End of the Fourth Millennium. In Gamdat Nasr: Period or Regional Style?, ed. Uwe Finkbeiner and Wolfgang Röllig, 212-28. Wiesbaden: Ludwig Reichert. 